\title{
LEVEL II SCOUR ANALYSIS FOR BRIDGE 34 (SHERUS00040034) ON US ROUTE 4, CROSSING THE OTTAUQUECHEE RIVER, SHERBURNE, VERMONT
}

U.S. Geological Survey Open-File Report 97-9

Prepared in cooperation with

VERMONT AGENCY OF TRANSPORTATION and

FEDERAL HIGHWAY ADMINISTRATION 


\section{LEVEL II SCOUR ANALYSIS FOR}

BRIDGE 34 (SHERUS00040034) ON

US ROUTE 4, CROSSING THE

OTTAUQUECHEE RIVER,

SHERBURNE, VERMONT

By ROBERT H. FLYNN AND TIMOTHY SEVERANCE

U.S. Geological Survey

Open-File Report 97-9

Prepared in cooperation with

VERMONT AGENCY OF TRANSPORTATION

and

FEDERAL HIGHWAY ADMINISTRATION 


\title{
U.S. DEPARTMENT OF THE INTERIOR BRUCE BABBITT, Secretary
}

\author{
U.S. GEOLOGICAL SURVEY \\ Gordon P. Eaton, Director
}

For additional information write to:

District Chief

U.S. Geological Survey 361 Commerce Way

Pembroke, NH 03275-3718
Copies of this report may be purchased from:

U.S. Geological Survey

Branch of Information Services

Open-File Reports Unit

Box 25286

Denver, CO 80225-0286 


\section{CONTENTS}

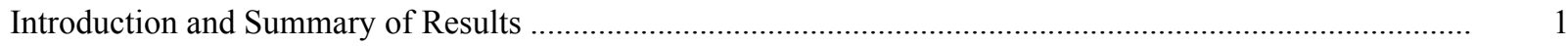

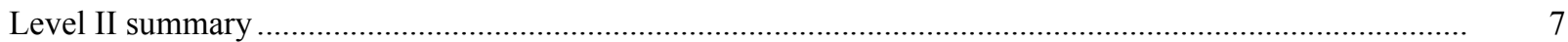

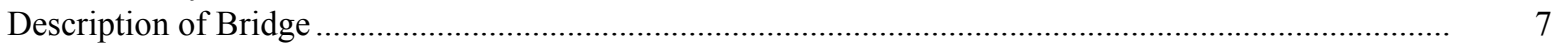

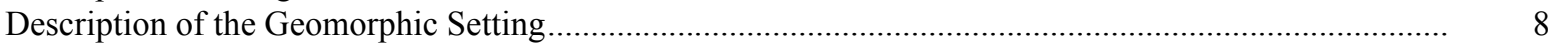

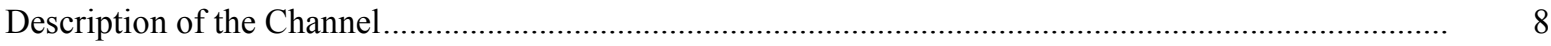

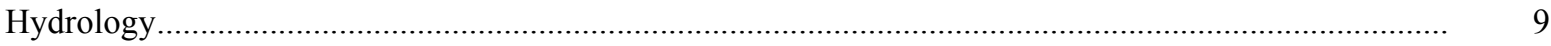

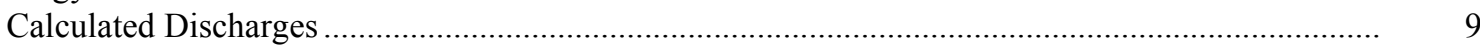

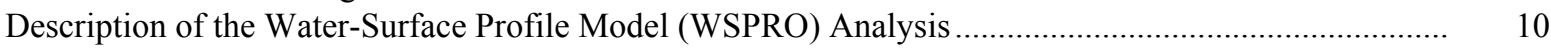

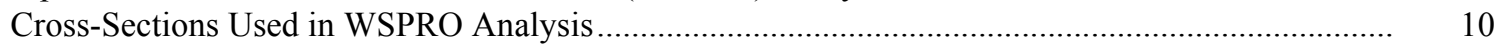

Data and Assumptions Used in WSPRO Model ...................................................................... 11

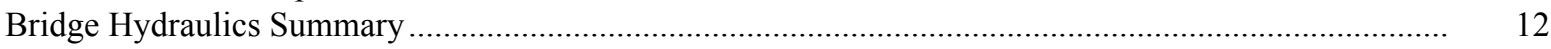

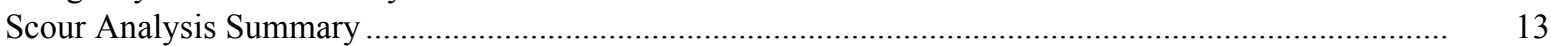

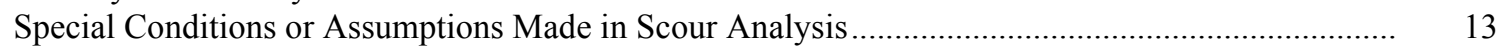

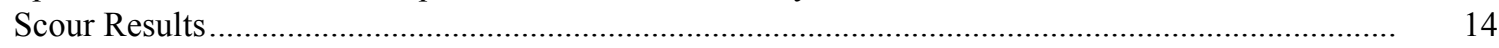

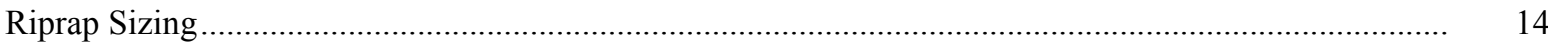

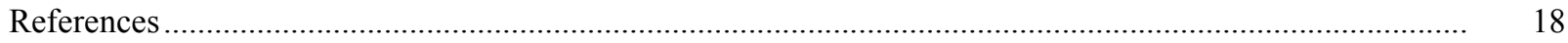

Appendixes:

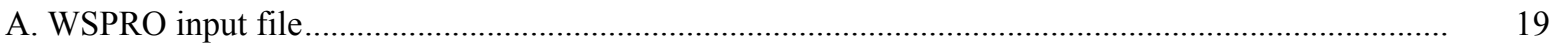

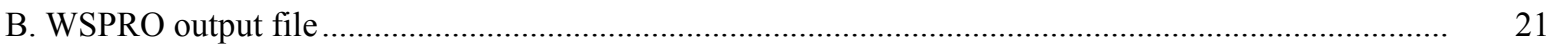

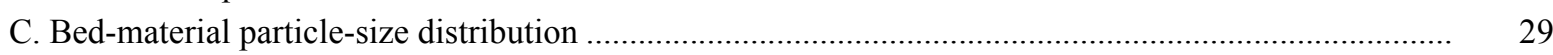

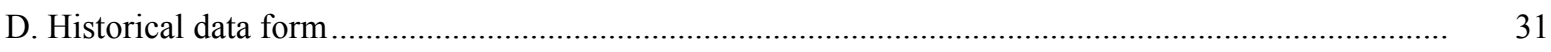

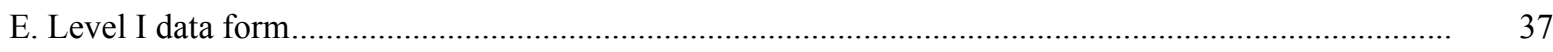

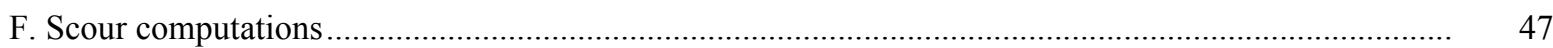

\section{FIGURES}

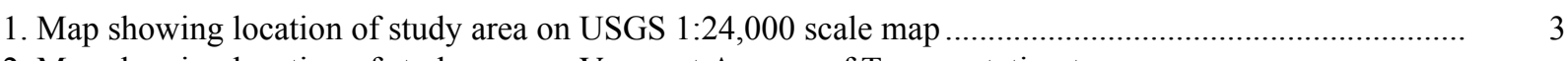

2. Map showing location of study area on Vermont Agency of Transportation town
highway map

3. Structure SHERUS00040034 viewed from upstream (September 25, 1995) ......................................... 5

4. Downstream channel viewed from structure SHERUS00040034 (September 25, 1995). ....................... 5

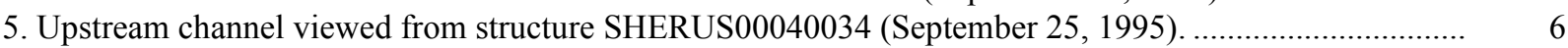

6. Structure SHERUS00040034 viewed from downstream (September 25, 1995) .................................. 6

7. Water-surface profiles for the 100- and 500-year discharges at structure

SHERUS00040034 on US Route 4, crossing Ottauquechee River,

Sherburne, Vermont.

8. Scour elevations for the 100- and 500-year discharges at structure

SHERUS00040034 on US Route 4, crossing Ottauquechee River,

Sherburne, Vermont.

\section{TABLES}

1. Remaining footing/pile depth at abutments for the 100-year discharge at structure

SHERUS00040034 on US Route 4, crossing Ottauquechee River,

Sherburne, Vermont.

2. Remaining footing/pile depth at abutments for the 500-year discharge at structure

SHERUS00040034 on US Route 4, crossing Ottauquechee River,

Sherburne, Vermont

6
(5 


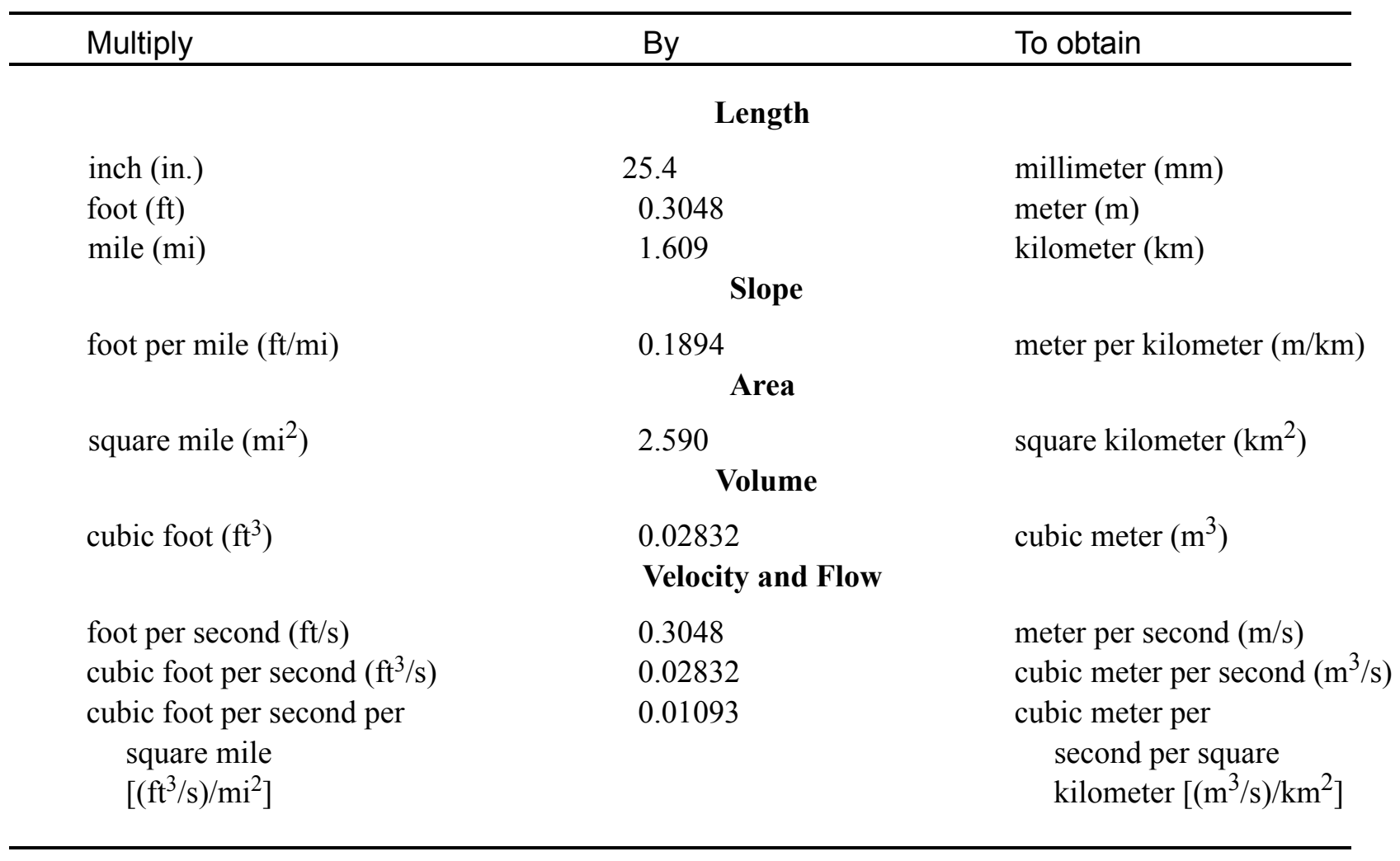

\section{OTHER ABBREVIATIONS}

$\begin{array}{lrlr}\mathrm{BF} & \text { bank full } & \text { LWW } & \text { left wingwall } \\ \mathrm{cfs} & \text { cubic feet per second } & \text { MC } & \text { main channel } \\ \mathrm{D}_{50} & \text { median diameter of bed material } & \text { RAB } & \text { right abutment } \\ \mathrm{DS} & \text { downstream } & \text { RABUT } & \text { face of right abutment } \\ \mathrm{elev} & \text { elevation } & \text { RB } & \text { right bank } \\ \mathrm{f} / \mathrm{p} & \text { flood plain } & \text { ROB } & \text { right overbank } \\ \mathrm{ft}^{2} & \text { square feet } & \text { RWW } & \text { right wingwall } \\ \mathrm{ft} / \mathrm{ft} & \text { feet per foot } & \text { TH } & \text { town highway } \\ \mathrm{JCT} & \text { junction } & \text { UB } & \text { under bridge } \\ \mathrm{LAB} & \text { left abutment } & \text { US } & \text { upstream } \\ \mathrm{LABUT} & \text { face of left abutment } & \text { USGS } & \text { United States Geological Survey } \\ \mathrm{LB} & \text { left bank } & \text { VTAOT Vermont Agency of Transportation } \\ \mathrm{LOB} & \text { left overbank } & \text { WSPRO } & \text { water-surface profile model }\end{array}$

In this report, the words "right" and "left" refer to directions that would be reported by an observer facing downstream. Sea level: In this report, "sea level" refers to the National Geodetic Vertical Datum of 1929-- a geodetic datum derived from a general adjustment of the first-order level nets of the United States and Canada, formerly called Sea Level Datum of 1929.

In the appendices, the above abbreviations may be combined. For example, USLB would represent upstream left bank. 


\title{
LEVEL II SCOUR ANALYSIS FOR BRIDGE 34 (SHERUS00040034) ON US ROUTE 4, CROSSING THE OTTAUQUECHEE RIVER, SHERBURNE, VERMONT
}

\author{
By Robert H. Flynn and Timothy Severance
}

\section{INTRODUCTION AND SUMMARY OF RESULTS}

This report provides the results of a detailed Level II analysis of scour potential at structure SHERUS00040034 on US Route 4 crossing the Ottauquechee River, Sherburne, Vermont (figures 1-8). A Level II study is a basic engineering analysis of the site, including a quantitative analysis of stream stability and scour (U.S. Department of Transportation, 1993). Results of a Level I scour investigation also are included in Appendix E of this report. A Level I investigation provides a qualitative geomorphic characterization of the study site. Information on the bridge, gleaned from Vermont Agency of Transportation (VTAOT) files, was compiled prior to conducting Level I and Level II analyses and is found in Appendix D.

The site is in the Green Mountain section of the New England physiographic province in central Vermont. The $25.8-\mathrm{mi}^{2}$ drainage area is in a predominantly rural and forested basin. In the vicinity of the study site, the surface cover is pasture upstream of the bridge while the immediate banks have dense woody vegetation. Downstream of the bridge, the banks are forested.

In the study area, the Ottauquechee River has an incised, straight channel with a slope of approximately $0.028 \mathrm{ft} / \mathrm{ft}$, an average channel top width of $66 \mathrm{ft}$ and an average channel depth of $5 \mathrm{ft}$. The channel bed material ranges from gravel to boulder with a median grain size $\left(\mathrm{D}_{50}\right)$ of $118.1 \mathrm{~mm}(0.387 \mathrm{ft})$. The geomorphic assessment at the time of the Level I and Level II site visit on September 25, 1995, indicated that the reach was stable.

The US Route 4 crossing of the Ottauquechee River is a 187-ft-long, two-lane bridge consisting of three steel-beam spans (Vermont Agency of Transportation, written communication, March 14, 1995). The bridge is supported by vertical, concrete abutments above spill-through stone fill ( $<36$ inches diameter). The channel is skewed approximately 60 degrees to the opening while the opening-skew-to-roadway is 60 degrees. Additional details describing conditions at the site are included in the Level II Summary and Appendices D and E. 
Scour depths and rock rip-rap sizes were computed using the general guidelines described in Hydraulic Engineering Circular 18 (Richardson and others, 1995). Total scour at a highway crossing is comprised of three components: 1) long-term streambed degradation; 2) contraction scour (due to accelerated flow caused by a reduction in flow area at a bridge) and; 3) local scour (caused by accelerated flow around piers and abutments). Total scour is the sum of the three components. Equations are available to compute depths for contraction and local scour and a summary of the results of these computations follows.

Contraction scour for all modelled flows was $0.0 \mathrm{ft}$. Abutment scour ranged from 4.7 to 7.4 $\mathrm{ft}$. The worst-case abutment scour occurred at the left abutment for the 500-year discharge. Pier scour ranged from 7.5 to $11.4 \mathrm{ft}$. The worst-case pier scour occurred at the incipientovertopping discharge. Additional information on scour depths and depths to armoring are included in the section titled "Scour Results". Scoured-streambed elevations, based on the calculated scour depths, are presented in tables 1 and 2. A cross-section of the scour computed at the bridge is presented in figure 8. Scour depths were calculated assuming an infinite depth of erosive material and a homogeneous particle-size distribution.

It is generally accepted that the Froehlich equation (abutment scour) gives "excessively conservative estimates of scour depths" (Richardson and others, 1995, p. 47). Usually, computed scour depths are evaluated in combination with other information including (but not limited to) historical performance during flood events, the geomorphic stability assessment, existing scour protection measures, and the results of the hydraulic analyses. Therefore, scour depths adopted by VTAOT may differ from the computed values documented herein. 


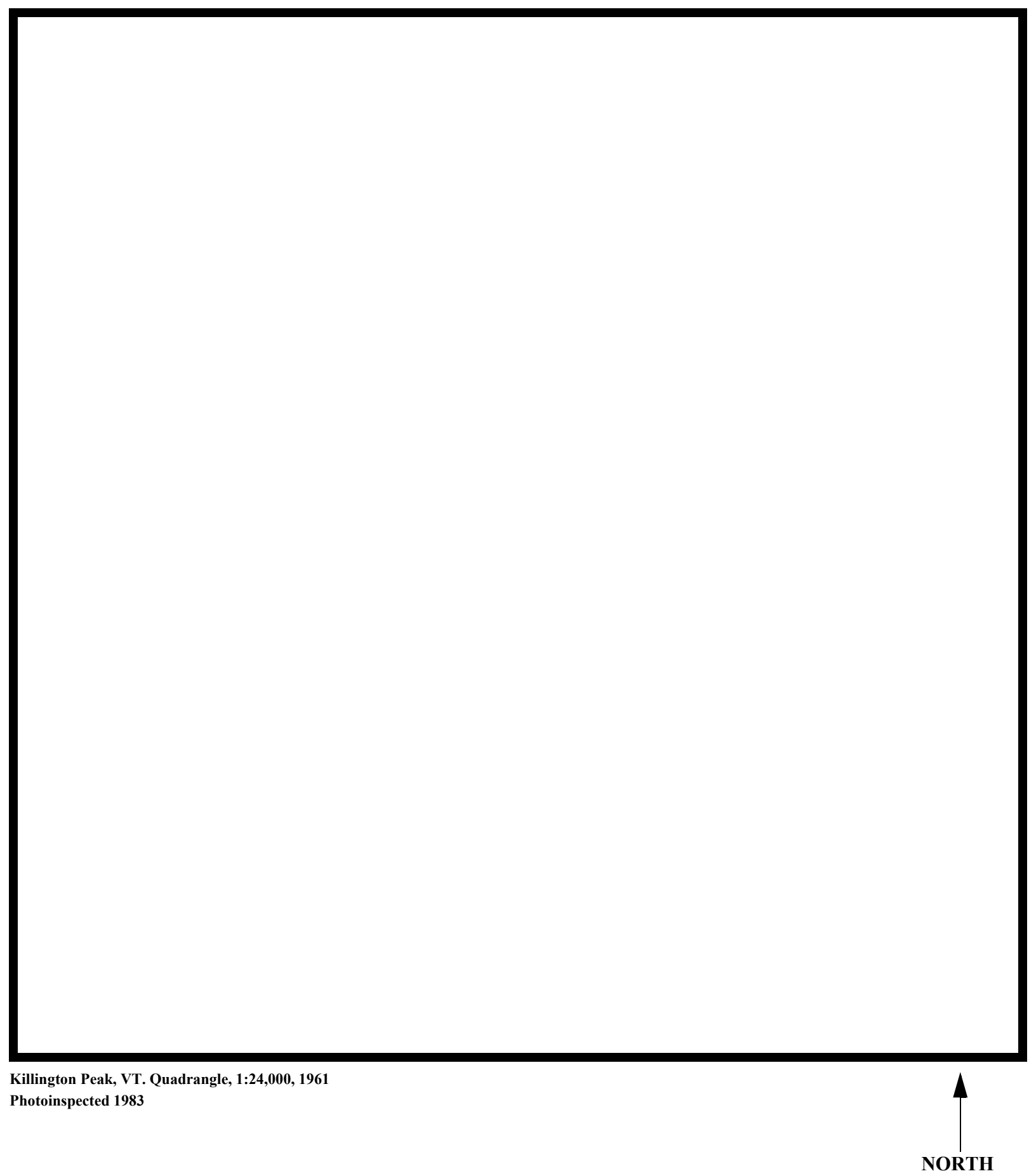

Figure 1. Location of study area on USGS 1:24,000 scale map. 
Figure 2. Location of study area on Vermont Agency of Transportation town highway map. 

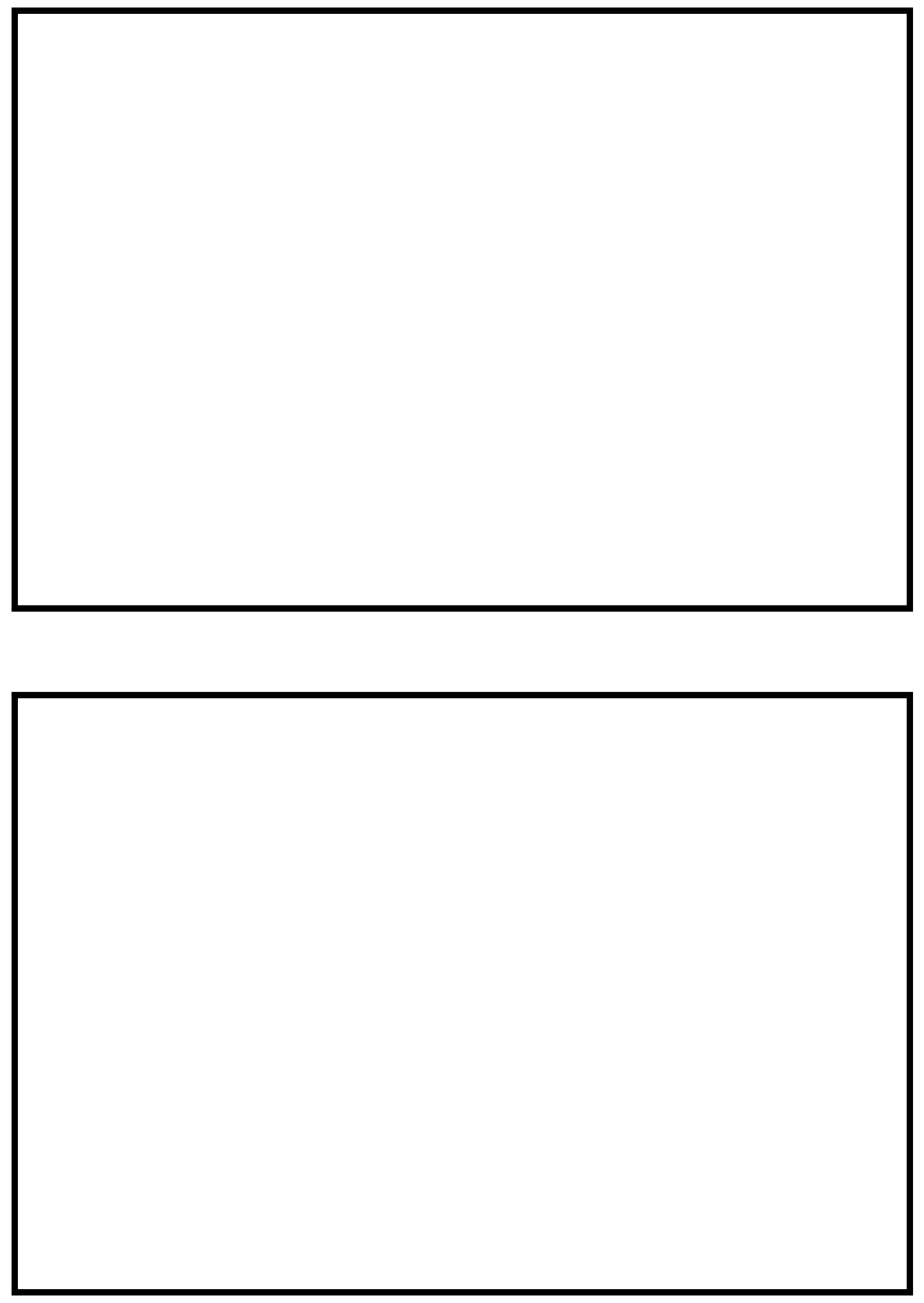

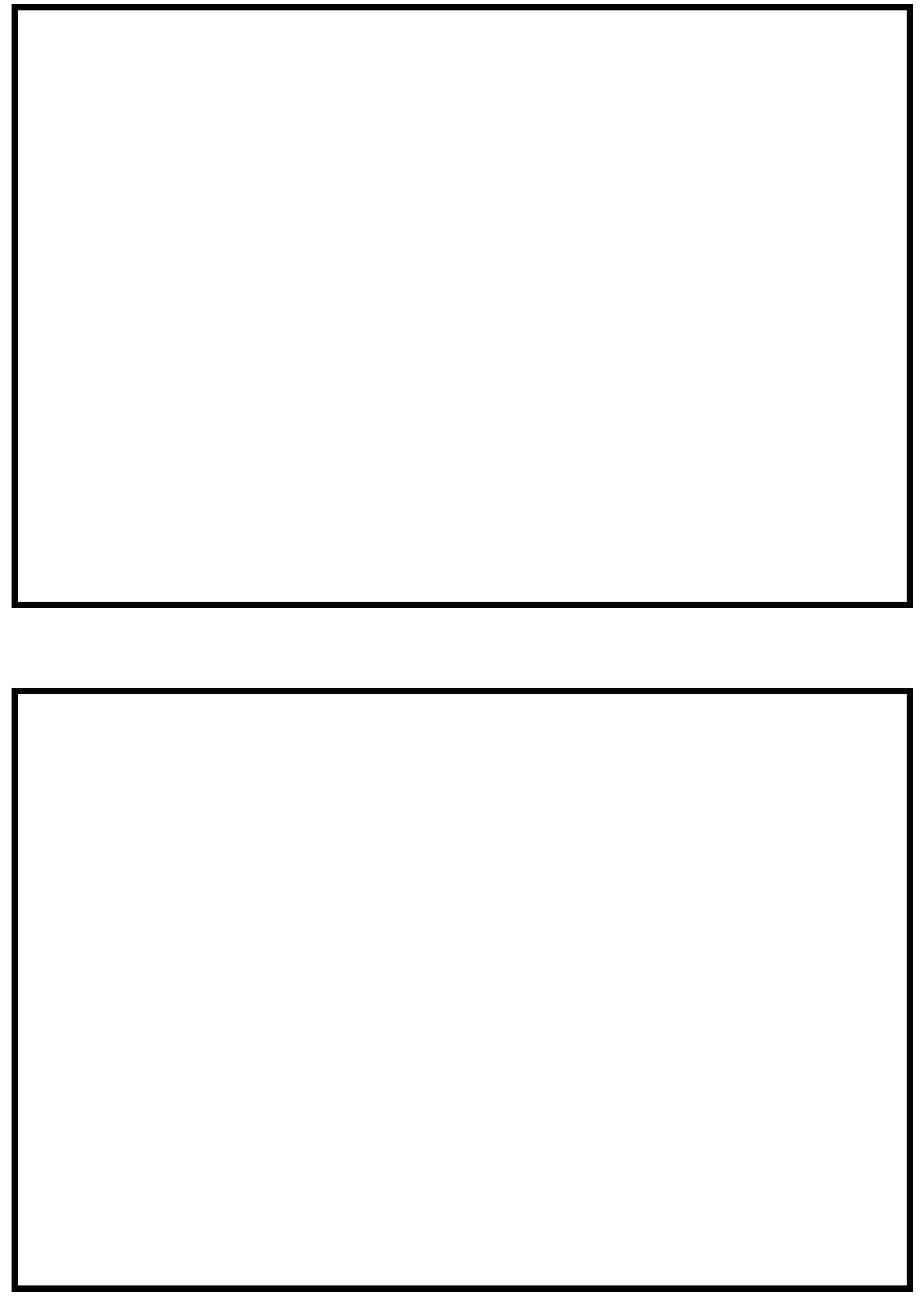


\section{LEVEL II SUMMARY}

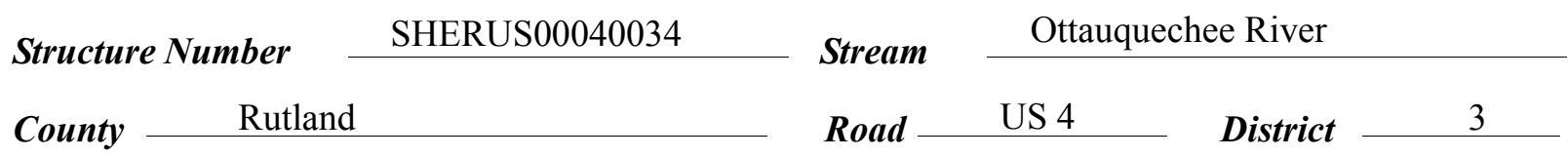

\section{Description of Bridge}

Bridge length $\frac{187}{} \boldsymbol{f t} \quad$ Bridge width $\frac{35.2}{f t} \quad$ Max span length $\frac{75}{f t}$

Alignment of bridge to road (on curve or straight)

Spill-through

Abutment type

Stone fill on abutment?

Yes

Embankment type

Straight

Sloping

$09 / 25 / 95$

Dato af incnortion

Type-3, on spill-through slope of abutments is in good condition.

Danauintion af atom a fill

The abutments and two piers are concrete.

Y

60

$\mathrm{N}$

Is bridge skewed to flood flow according to 'survey?

Angle

$09 / 25 / 95$

Debris accumulation on bridge at time of Level I or Level II site visit:

\begin{tabular}{|c|c|c|c|}
\hline & $\begin{array}{c}\text { Date of insnortinn } \\
\underline{0}\end{array}$ & $\begin{array}{l}\text { Percent of alommat } \\
\text { blocked inortzontatly }\end{array}$ & $\begin{array}{l}\text { Percent of } 09 / 25 / \text { el } \\
\text { blocked verticatty }\end{array}$ \\
\hline Level I & $\underline{95}$ & 0 & 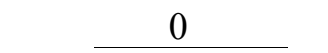 \\
\hline $\begin{array}{l}\text { Level II } \\
\text { bank. }\end{array}$ & \multicolumn{3}{|c|}{ Low. There is some debris caught on boulders on the upstream right } \\
\hline
\end{tabular}

Some trees with exposed roots and boulders in the channel and along upstream banks may

Doscriho anv fonturos noar ar at tho hridoo that mav, affort flow (includo ahsorvation dato) eventually affect flow (observed 09/25/95). 


\section{Description of the Geomorphic Setting}

General topography The channel is located within a 280 foot-wide, flat to slightly irregular flood plain with steep valley walls on both sides.

Geomorphic conditions at bridge site: downstream (DS), upstream (US)

Date of inspection $\quad 09 / 25 / 95$

DS left: $\quad$ Steep channel bank.

DS right: $\quad$ Moderately sloped overbank.

US left: $\quad$ Moderately sloped overbank.

US right: $\quad$ Moderately sloped overbank.

\section{Description of the Channel}

$\begin{array}{llll}\text { Average top width } & 66 & \text { Average depth } & 5 \\ & \text { Boulder/Bedrock } & \text { Boulder/Cobble }\end{array}$

Predominant bed material

Bank material

Straight and stable

with non-alluvial channel boundaries and little to no flood plain.

$09 / 25 / 95$

Vegetative co 1 Trees and brush

DS left: $\quad$ Trees

DS right: Trees

US left: $\quad$ Trees.

US right: $\quad \underline{\mathrm{Y}}$

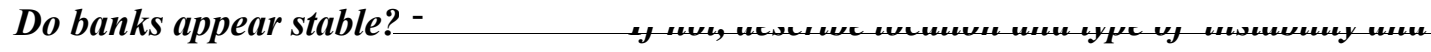

date of observatton.

25/95 noted some debris on boulders along the upstream right bank channel. Describe any obstructions in channel and date of observation. 


\section{Hydrology}

Drainage area $\stackrel{25.8}{\mathbf{m}} \boldsymbol{m i}^{2}$

Percentage of drainage area in physiographic provinces: (approximate)

Physiographic province/section Green Mountain
Percent of drainage area 100

Is drainage area considered rural or urban? Rural Describe any significant

urbanization: There are some houses along the downstream left overbank

Is there a USGS gage on the stream of interest?

No

USGS gage description

USGS gage number

Gage drainage area $\mathrm{mi}^{2}$

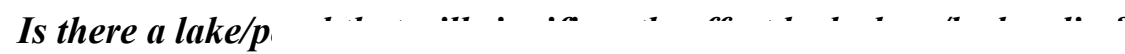

No

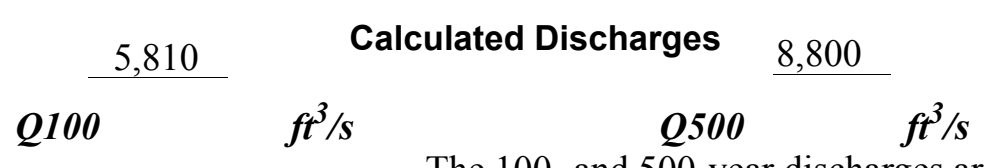

The 100- and 500-year discharges are based on a

drainage area relationship. [(25.8/23.1)exp 0.5] with bridge number 28 in Sherburne. Bridge number 28 crosses the Ottauquechee River upstream of this site and has flood frequency estimates available from the VTAOT database. The drainage area above bridge number 28 is 23.1 square miles. 


\section{Description of the Water-Surface Profile Model (WSPRO) Analysis}

Datum for WSPRO analysis (USGS survey, sea level, VTAOT plans)

USGS survey

Datum tie between USGS survey and VTAOT plans

Yes. USGS survey elevations

adjusted to VTAOT plans based on USLAB Bridge seat elevation.

Description of reference marks used to determine USGS datum.

RM1 is a chiseled X on top of curbing on the downstream end of the right abutment (elev.

$1095.42 \mathrm{ft}$, arbitrary survey datum). RM2 is a brass survey disk on top of curbing on the

upstream end of the left abutment (elev. $1104.18 \mathrm{ft}$, arbitrary survey datum).

\section{Cross-Sections Used in WSPRO Analysis}

\begin{tabular}{cccl}
\hline${ }^{1}$ Cross-section & $\begin{array}{c}\text { Section } \\
\text { Reference } \\
\text { Distance } \\
\text { (SRD) in feet }\end{array}$ & $\begin{array}{c}{ }^{2} \text { Cross-section } \\
\text { development }\end{array}$ & \multicolumn{1}{c}{ Comments } \\
\hline EXITX & -113 & 1 & Exit section \\
FULLV & 0 & 2 & $\begin{array}{l}\text { Downstream Full-valley } \\
\text { section (Templated from } \\
\text { EXITX) }\end{array}$ \\
BRIDG & 0 & 1 & $\begin{array}{l}\text { Bridge section } \\
\text { Road Grade section }\end{array}$ \\
RDWAY & 33 & 1 & $\begin{array}{l}\text { Modelled Approach sec- } \\
\text { tion (Templated from } \\
\text { APTEM) }\end{array}$ \\
APTEM & 155 & 2 & $\begin{array}{l}\text { Approach section as sur- } \\
\text { veyed (Used as a tem- } \\
\text { plate) }\end{array}$ \\
\hline
\end{tabular}

${ }^{1}$ For location of cross-sections see plan-view sketch included with Level I field form, Appendix E. For more detail on how cross-sections were developed see WSPRO input file. 


\section{Data and Assumptions Used in WSPRO Model}

Hydraulic analyses of the reach were done by use of the Federal Highway Administration's WSPRO step-backwater computer program (Shearman and others, 1986, and Shearman, 1990). The analyses reported herein reflect conditions existing at the site at the time of the study. Furthermore, in the development of the model it was necessary to assume no accumulation of debris or ice at the site. Results of the hydraulic model are presented in the Bridge Hydraulic Summary, Appendix B, and figure 7.

Channel roughness factors (Manning's " $n$ ") used in the hydraulic model were estimated using field inspections at each cross section following the general guidelines described by Arcement and Schneider (1989). Final adjustments to the values were made during the modelling of the reach. Channel " $n$ " values for the reach ranged from 0.047 to 0.055 , and overbank "n" values ranged from 0.075 to 0.100 .

Normal depth at the exit section (EXITX) was assumed as the starting water surface. This depth was computed by use of the slope-conveyance method outlined in the user's manual for WSPRO (Shearman, 1990). The slope used was $0.0276 \mathrm{ft} / \mathrm{ft}$ which was determined from surveyed thalweg and water surface points downstream of the bridge.

The surveyed approach section (APTEM) was moved along the approach channel slope $(0.0353 \mathrm{ft} / \mathrm{ft})$ to establish the modelled approach section (APPRO), one bridge length upstream of the upstream face as recommended by Shearman and others (1986). This approach also provides a consistent method for determining scour variables.

For the 100-year, 500-year and incipient-overtopping discharge, WSPRO assumes critical depth at the exit and full valley sections. Supercritical models were developed for these discharges. Analyzing both the supercritical and subcritical profiles for each discharge, it can be determined that the water surface profile is just below critical at the exit and full valley sections. Thus, the assumptions of critical depth are satisfactory solutions. 


\section{Bridge Hydraulics Summary}

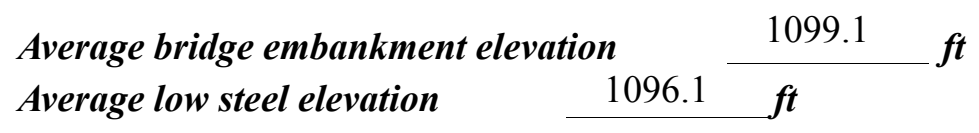

100-year discharge $\quad 5,810 \quad \mathrm{ft}^{3} / \mathrm{s}$

Water-surface elevation in bridge opening $1091.1 \mathrm{ft}$

Road overtopping? ___ N Discharge over road __

Area of flow in bridge opening $\quad 476 \quad \mathrm{ft}^{2}$

Average velocity in bridge opening $12.2 \mathrm{ft} / \mathrm{s}$

Maximum WSPRO tube velocity at bridge $\quad 15.4 \mathrm{ft} / \mathrm{s}$

Water-surface elevation at Approach section with bridge 1093.9

Water-surface elevation at Approach section without bridge $\quad\left[\begin{array}{l}1093.4 \\ \text { W }\end{array}\right.$

Amount of backwater caused by bridge $\quad 0.5$ it

500-year discharge $\quad 8,800 \quad \mathrm{ft}^{3} / \mathrm{s}$

Water-surface elevation in bridge opening $\quad 1096.1 \mathrm{ft}$

Road overtopping? ___ Y Discharge over road _ $\quad 2,750^{\circ}$

\begin{tabular}{lll} 
Area of flow in bridge opening & $706 \quad \boldsymbol{f t}^{2}$ \\
\cline { 2 - 2 } Average velocity in bridge opening & 8.6
\end{tabular}

Maximum WSPRO tube velocity at bridge 10.5 's

Water-surface elevation at Approach section with bridge 1097.9

Water-surface elevation at Approach section without bridge $\quad 1095.2$

Amount of backwater caused by bridge 2.7 .

Incipient overtopping discharge $\quad 6,600 \quad \mathrm{ft}^{3} / \mathrm{s}$

Water-surface elevation in bridge opening $1091.6 \mathrm{t}$

Area of flow in bridge opening $\quad 519 \quad \mathrm{ft}^{2}$

Average velocity in bridge opening $\quad 12.7 \quad \mathrm{ft} / \mathrm{s}$

Maximum WSPRO tube velocity at bridge $\quad 15.9 \quad \mathrm{ft} / \mathrm{s}$

Water-surface elevation at Approach section with bridge 1094.4

Water-surface elevation at Approach section without bridge $\quad 1093.9$

Amount of backwater caused by bridge $\quad 0.5 \quad$ it 


\section{Scour Analysis Summary}

\section{Special Conditions or Assumptions Made in Scour Analysis}

Scour depths were computed using the general guidelines described in Hydraulic Engineering Circular 18 (Richardson and others, 1995). Scour depths were calculated assuming an infinite depth of erosive material and a homogeneous particle-size distribution. The results of the scour analysis are presented in tables 1 and 2 and a graph of the scour depths is presented in figure 8 .

Contraction scour was computed by use of Laursen's live-bed contraction scour equation (Richardson and others, 1995, p. 32, equation 20) for the 100-year discharge and incipient road-overflow models. The 500-year discharge resulted in unsubmerged orifice flow. Contraction scour at bridges with orifice flow is best estimated by use of the Chang pressureflow scour equation (oral communication, J. Sterling Jones, October 4, 1996). Thus, contraction scour for the 500-year discharge was computed by the Chang equation (Richarson and others, 1995, p. 145-146) . The results of Laursen's equation for the 500-year event were also computed and can be found in appendix F.

Abutment scour for the left and right abutments was computed by use of the Froehlich equation (Richardson and others, 1995, p. 48, equation 28). Variables for the Froehlich equation include the Froude number of the flow approaching the embankments, the length of the embankment blocking flow, and the depth of flow approaching the embankment less any roadway overtopping. Because scour processes on the spill-through embankment material is uncertain, the scour depth at the vertical concrete abutment walls is unknown. Therefore, the total scour depths were applied for the entire spill-through embankment below the elevation at the toe of each embankment and extended to the vertical concrete abutment wall as shown in figure 8 .

Pier scour was computed based on an equation developed by Colorado State University (CSU) (Richardson and others, 1995, p. 36, equation 21). The variables used by the CSU equation include pier dimensions, flow approach depth and velocity, Froude number, and multiplicative factors for pier shape, attack angle, bed conditions, and armoring (see Appendix F). 


\section{Scour Results}

100-yr discharge 500-yr discharge

Incipient

overtopping

Contraction scour:

(Scour depths in feet)

Main channel

Live-bed scour

$$
0.0
$$

Clear-water scour

Depth to armoring

Left overbank

Right overbank

Local scour:

Abutment scour

Left abutment

Right abutment

Pier scour

Pier 1

Pier 2

Pier 3
6.6

4.7-

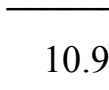

10.9
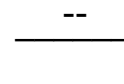

7.4

6.9-

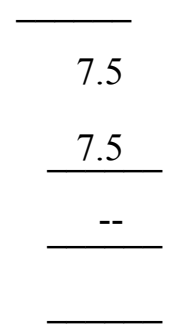

0.0

$--$

$12.7^{-}$

--

--

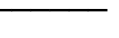

\section{Riprap Sizing}

Incipient overtopping 100-yr discharge 500-yrdischarge discharge

2.0 ( $D_{50}$ in feet)

Abutments:

Left abutment

2.0 2.5

2.1

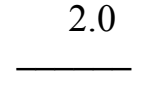

$2.2^{-}$

$0.8^{-}$

$2.4^{-}$

2.2

0.8

2.4

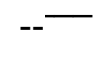

Pier 2 


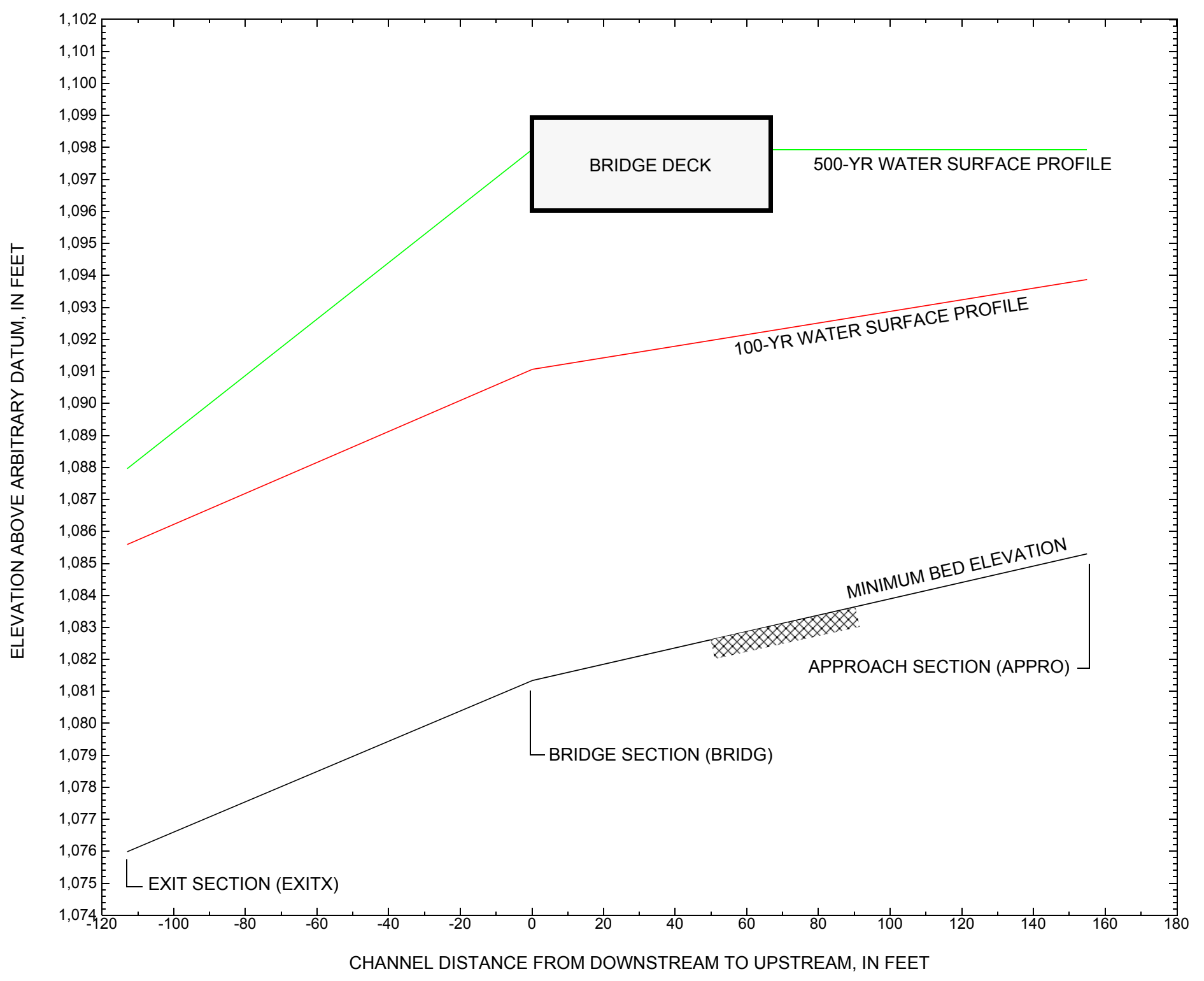

Figure 7. Water-surface profiles for the 100- and 500-yr discharges at structure SHERUS00040034 on US Route 4, crossing Ottauquechee River, Sherburne, Vermont. 


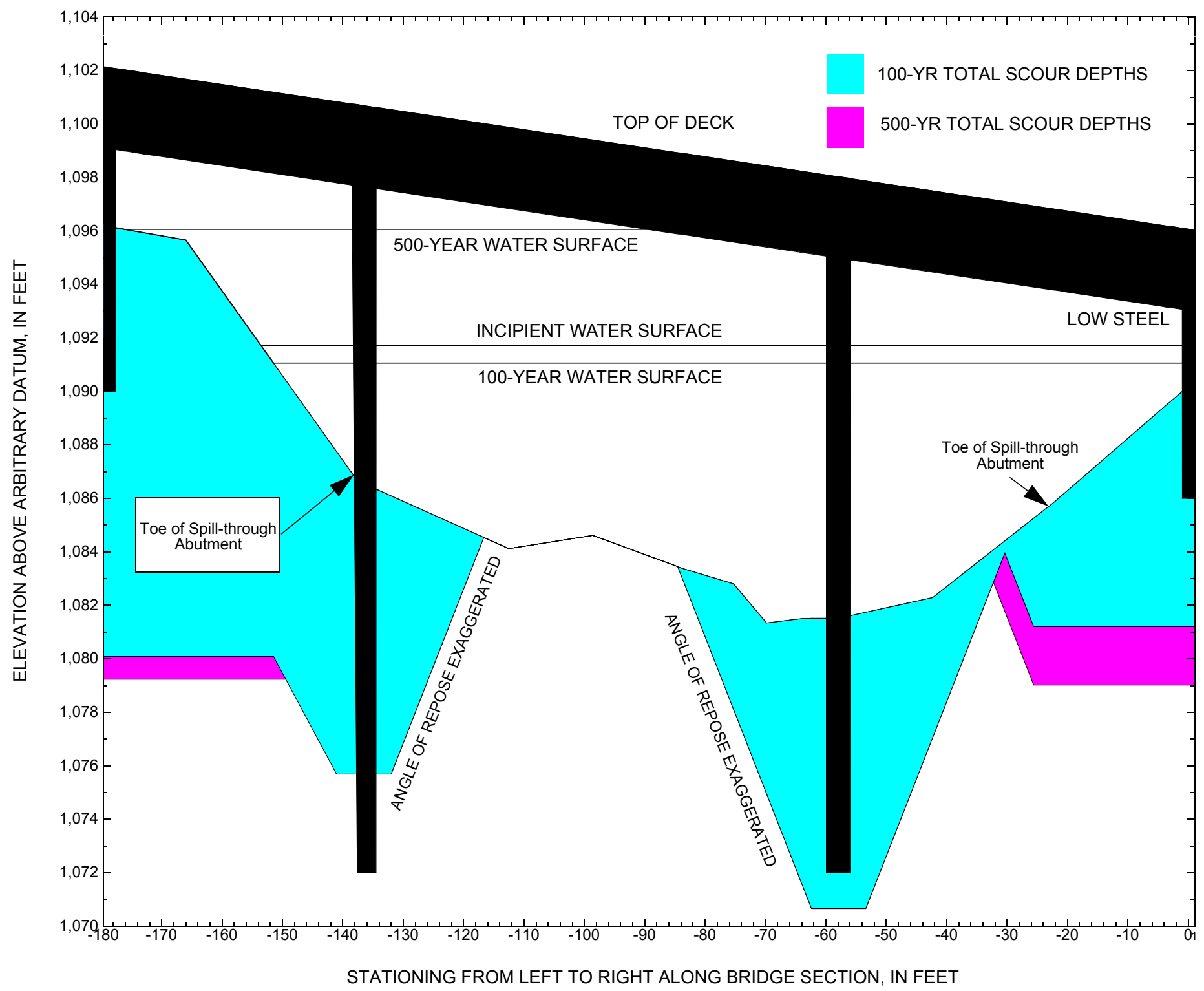

Figure 8. Scour elevations for the 100-yr and 500-yr discharges at structure SHERUS00040034 on US Route 4, crossing Ottauquechee River, Sherburne, Vermont. 
Table 1. Remaining footing/pile depth at abutments for the 100-year discharge at structure SHERUS00040034 on US Route 4, crossing Ottauquechee River, Sherburne, Vermont.

[VTAOT, Vermont Agency of Transportation; --,no data]

\begin{tabular}{|c|c|c|c|c|c|c|c|c|c|c|c|}
\hline Description & Station ${ }^{1}$ & $\begin{array}{l}\text { VTAOT } \\
\text { minimum } \\
\text { low-chord } \\
\text { elevation } \\
\text { (feet) }\end{array}$ & $\begin{array}{l}\text { Surveyed } \\
\text { minimum } \\
\text { low-chord } \\
\text { elevation }{ }^{2} \\
\quad \text { (feet) }\end{array}$ & $\begin{array}{l}\text { Bottom of } \\
\text { footing } \\
\text { elevation } \\
\text { (feet) }\end{array}$ & $\begin{array}{c}\text { Channel } \\
\text { elevation at } \\
\text { abutment/ } \\
\text { pier }^{2} \\
\text { (feet) }\end{array}$ & $\begin{array}{l}\text { Contraction } \\
\text { scour depth } \\
\text { (feet) }\end{array}$ & $\begin{array}{l}\text { Abutment } \\
\text { scour } \\
\text { depth } \\
\text { (feet) }\end{array}$ & $\begin{array}{l}\text { Pier } \\
\text { scour } \\
\text { depth } \\
\text { (feet) }\end{array}$ & $\begin{array}{l}\text { Depth of } \\
\text { total scour } \\
\text { (feet) }\end{array}$ & $\begin{array}{c}\text { Elevation of } \\
\text { scour }^{2} \\
\text { (feet) }\end{array}$ & $\begin{array}{c}\text { Remaining } \\
\text { footing/pile } \\
\text { depth } \\
\text { (feet) }\end{array}$ \\
\hline \multicolumn{12}{|c|}{100 -yr. discharge is 5,810 cubic-feet per second } \\
\hline Left abutment & -178.6 & 1099.3 & 1099.3 & 1090.0 & 1096.2 & 0.0 & -- & -- & -- & -- & -9.9 \\
\hline Toe of LABUT & -137.6 & -- & -- & -- & 1086.7 & 0.0 & 6.6 & -- & 6.6 & 1080.1 & -- \\
\hline Left Pier & -136.5 & -- & -- & 1072.0 & 1086.6 & 0.0 & -- & 10.9 & 10.9 & 1075.7 & 3.7 \\
\hline Right Pier & -57.9 & -- & -- & 1072.0 & 1081.5 & 0.0 & -- & 10.9 & 10.9 & 1070.6 & -1.4 \\
\hline Toe of RABUT & -22.1 & -- & -- & -- & 1085.9 & 0.0 & 4.7 & -- & 4.7 & 1081.2 & -- \\
\hline Right abutment & 0.0 & 1092.8 & 1092.8 & 1086.0 & 1090.2 & 0.0 & -- & -- & -- & -- & -4.8 \\
\hline
\end{tabular}

1.Measured along the face of the most constricting side of the bridge.

2.Arbitrary datum for this study.

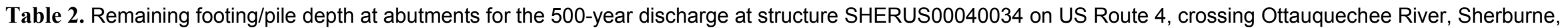
Vermont.

[VTAOT, Vermont Agency of Transportation; --, no data]

\begin{tabular}{|c|c|c|c|c|c|c|c|c|c|c|c|}
\hline Description & Station ${ }^{1}$ & $\begin{array}{l}\text { VTAOT } \\
\text { minimum } \\
\text { low-chord } \\
\text { elevation } \\
\text { (feet) }\end{array}$ & $\begin{array}{l}\text { Surveyed } \\
\text { minimum } \\
\text { low-chord } \\
\text { elevation } \\
\text { (feet) }\end{array}$ & $\begin{array}{c}\text { Bottom of } \\
\text { footing } \\
\text { elevation } \\
\text { (feet) }\end{array}$ & $\begin{array}{l}\text { Channel } \\
\text { elevation at } \\
\text { abutment/ } \\
\text { pier }^{2} \\
\text { (feet) }\end{array}$ & $\begin{array}{l}\text { Contraction } \\
\text { scour depth } \\
\text { (feet) }\end{array}$ & $\begin{array}{l}\text { Abutment } \\
\text { scour } \\
\text { depth } \\
\text { (feet) }\end{array}$ & $\begin{array}{l}\text { Pier } \\
\text { scour } \\
\text { depth } \\
\text { (feet) }\end{array}$ & $\begin{array}{l}\text { Depth of } \\
\text { total scour } \\
\text { (feet) }\end{array}$ & $\begin{array}{c}\text { Elevation of } \\
\text { scour }^{2} \\
\text { (feet) }\end{array}$ & $\begin{array}{c}\text { Remaining } \\
\text { footing/pile } \\
\text { depth } \\
\text { (feet) }\end{array}$ \\
\hline \multicolumn{12}{|c|}{500 -yr. discharge is 8,800 cubic-feet per second } \\
\hline Left abutment & -178.6 & 1099.3 & 1099.3 & 1090.0 & 1096.2 & 0.0 & -- & -- & -- & -- & -10.8 \\
\hline Toe of LABUT & -137.6 & -- & -- & -- & 1086.7 & 0.0 & 7.4 & -- & 7.4 & 1079.3 & -- \\
\hline Left Pier & -136.5 & -- & -- & 1072.0 & 1086.6 & 0.0 & -- & 7.5 & 7.5 & 1079.1 & 7.1 \\
\hline Right Pier & -57.9 & -- & -- & 1072.0 & 1081.5 & 0.0 & -- & 7.5 & 7.5 & 1074.0 & 2.0 \\
\hline Toe of RABUT & -22.1 & -- & -- & -- & 1085.9 & 0.0 & 6.9 & -- & 6.9 & 1079.0 & -- \\
\hline Right abutmen & 0.0 & 1092.8 & 1092.8 & 1086.0 & 1090.2 & 0.0 & -- & -- & -- & -- & -7.0 \\
\hline
\end{tabular}

1.Measured along the face of the most constricting side of the bridge. 


\section{SELECTED REFERENCES}

Arcement, G.J., Jr., and Schneider, V.R., 1989, Guide for selecting Manning's roughness coefficients for natural channels and flood plains: U.S. Geological Survey Water-Supply Paper 2339, 38 p.

Barnes, H.H., Jr., 1967, Roughness characteristics of natural channels: U.S. Geological Survey Water-Supply Paper 1849,213 p.

Benson, M. A., 1962, Factors Influencing the Occurrence of Floods in a Humid Region of Diverse Terrain: U.S. Geological Survey WaterSupply Paper 1580-B, 64 p.

Brown, S.A. and Clyde, E.S., 1989, Design of riprap revetment: Federal Highway Administration Hydraulic Engineering Circular No. 11, Publication FHWA-IP-89-016, 156 p.

Federal Highway Administration, 1983, Runoff estimates for small watersheds and development of sound design: Federal Highway Administration Report FHWA-RD-77-158

Froehlich, D.C., 1989, Local scour at bridge abutments in Ports, M.A., ed., Hydraulic Engineering--Proceedings of the 1989 National Conference on Hydraulic Engineering: New York, American Society of Civil Engineers, p. 13-18.

Hayes, D.C.,1993, Site selection and collection of bridge-scour data in Delaware, Maryland, and Virginia: U.S. Geological Survey WaterResources Investigation Report 93-4017, 23 p.

Interagency Advisory Committee on Water Data, 1982, Guidelines for determining flood flow frequency: U.S. Geological Survey, Bulletin 17B of the Hydrology Subcommittee, 190 p.

Johnson, C.G. and Tasker, G.D.,1974, Progress report on flood magnitude and frequency of Vermont streams: U.S. Geological Survey OpenFile Report 74-130, 37 p.

Lagasse, P.F., Schall, J.D., Johnson, F., Richardson, E.V., Chang, F., 1995, Stream Stability at Highway Structures: Federal Highway Administration Hydraulic Engineering Circular No. 20, Publication FHWA-IP-90-014, 144 p.

Laursen, E.M., 1960, Scour at bridge crossings: Journal of the Hydraulics Division, American Society of Civil Engineers, v. 86, no. HY2, p. 39-53.

Potter, W. D., 1957a, Peak rates of runoff in the Adirondack, White Mountains, and Maine woods area, Bureau of Public Roads

Potter, W. D., 1957b, Peak rates of runoff in the New England Hill and Lowland area, Bureau of Public Roads

Richardson, E.V. and Davis, S.R., 1995, Evaluating scour at bridges: Federal Highway Administration Hydraulic Engineering Circular No. 18, Publication FHWA-IP-90-017, 204 p.

Richardson, E.V., Simons, D.B., and Julien, P.Y., 1990, Highways in the river environment: Federal Highway Administration Publication FHWA-HI-90-016.

Ritter, D.F., 1984, Process Geomorphology: W.C. Brown Co., Debuque, Iowa, 603 p.

Shearman, J.O., 1990, User's manual for WSPRO--a computer model for water surface profile computations: Federal Highway Administration Publication FHWA-IP-89-027, 187 p.

Shearman, J.O., Kirby, W.H., Schneider, V.R., and Flippo, H.N., 1986, Bridge waterways analysis model; research report: Federal Highway Administration Publication FHWA-RD-86-108, 112 p.

Talbot, A.N., 1887, The determination of water-way for bridges and culverts.

U.S. Department of Transportation, 1993, Stream stability and scour at highway bridges, Participant Workbook: Federal Highway Administration Publication FHWA HI-91-011.

U.S. Geological Survey, 1961, Killington Peak, Vermont 7.5 Minute Series quadrangle map: U.S. Geological Survey Topographic Maps, Photoinspected 1983, Scale 1:24,000. 


\section{APPENDIX A: \\ WSPRO INPUT FILE}




\section{WSPRO INPUT FILE}

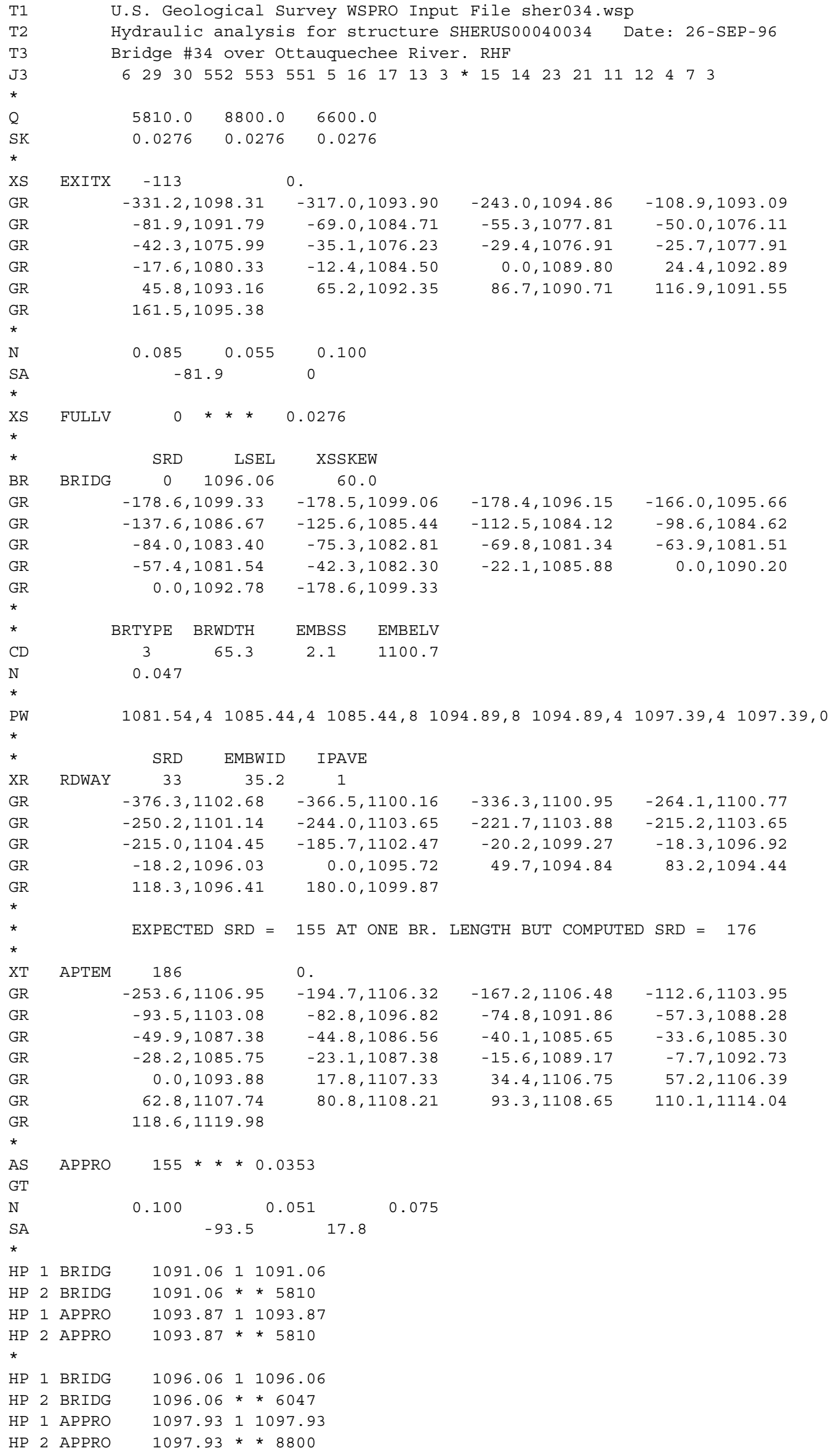




\section{APPENDIX B: \\ WSPRO OUTPUT FILE}




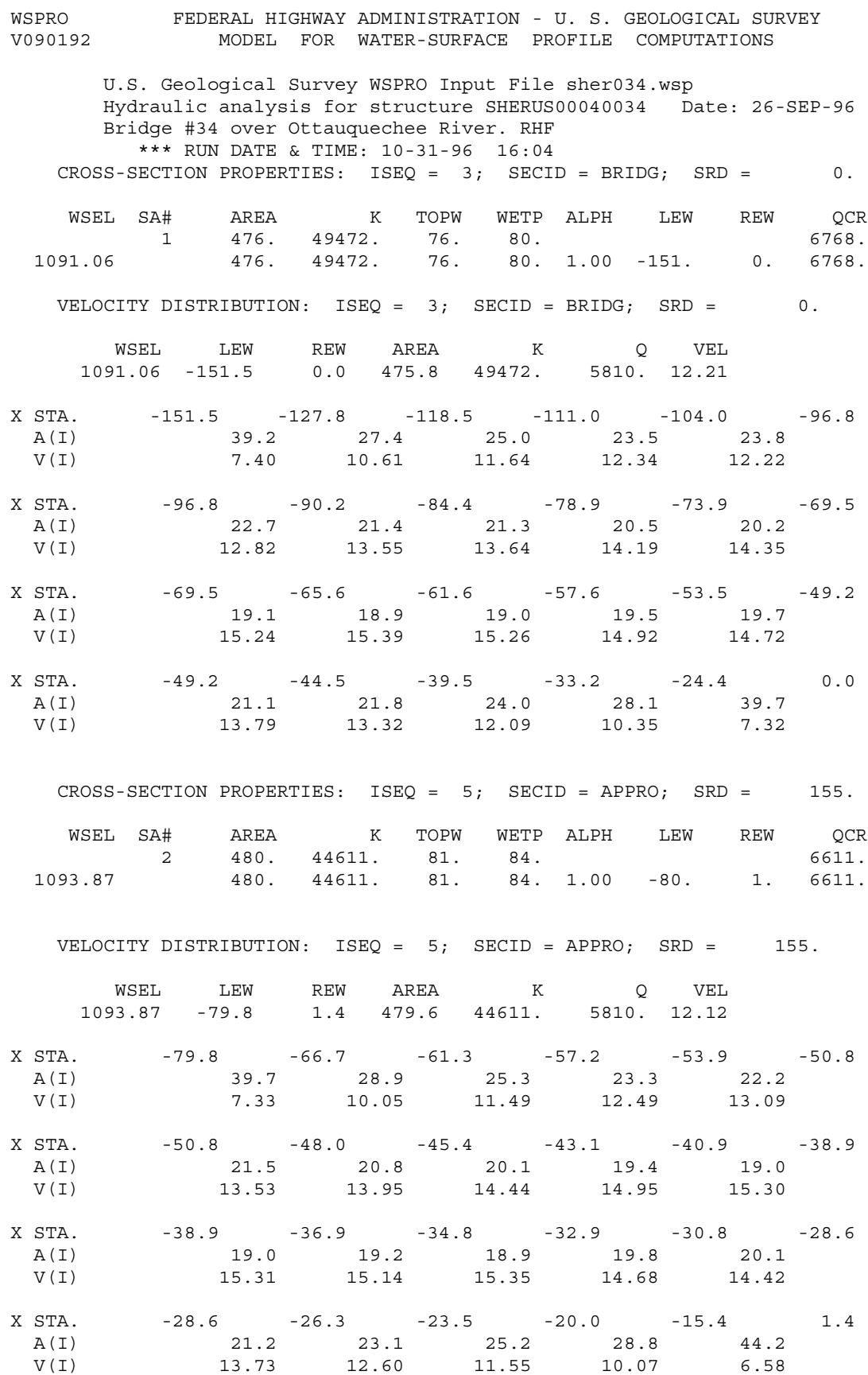


WSPRO OUTPUT FILE (continued)

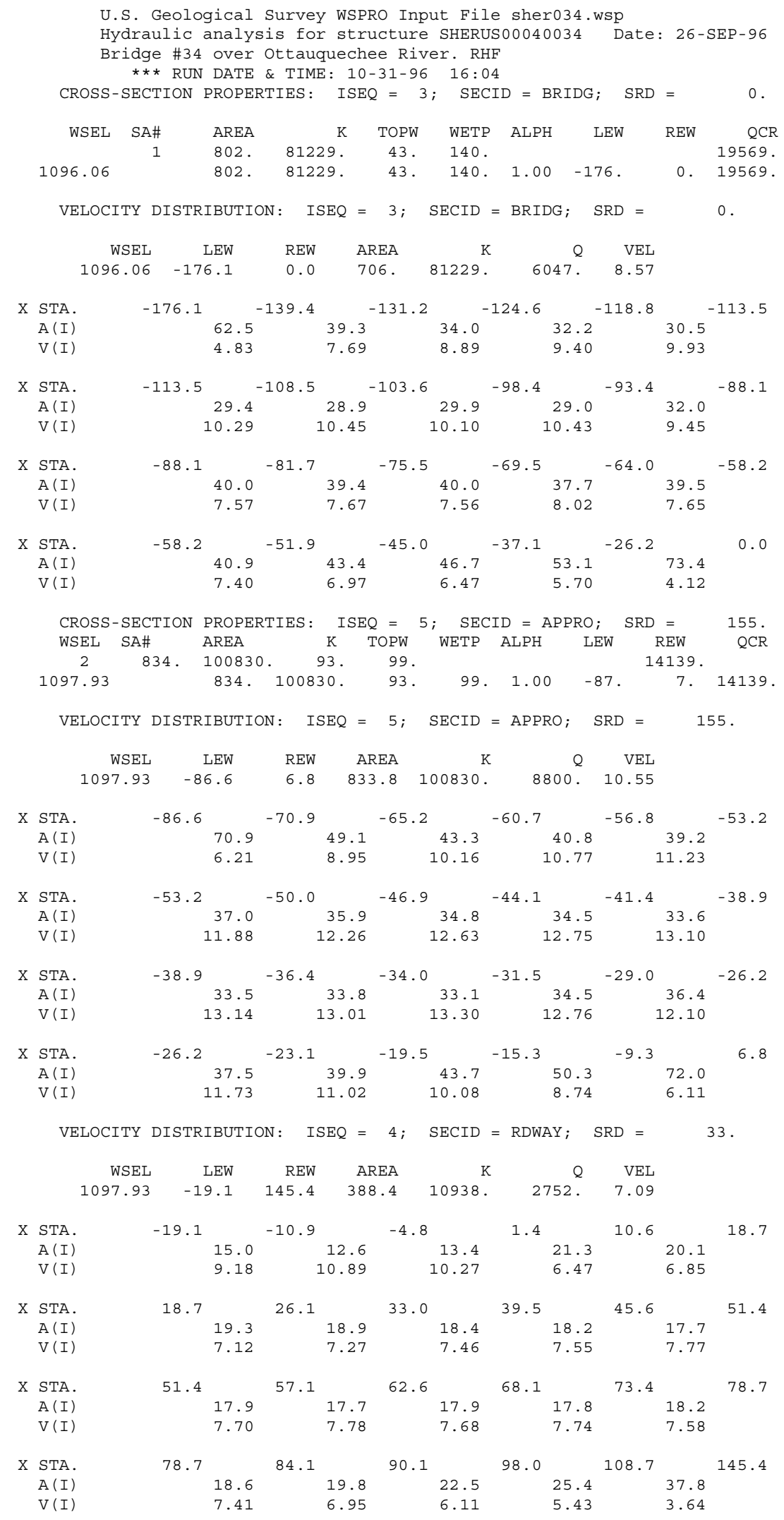


WSPRO OUTPUT FILE (continued)

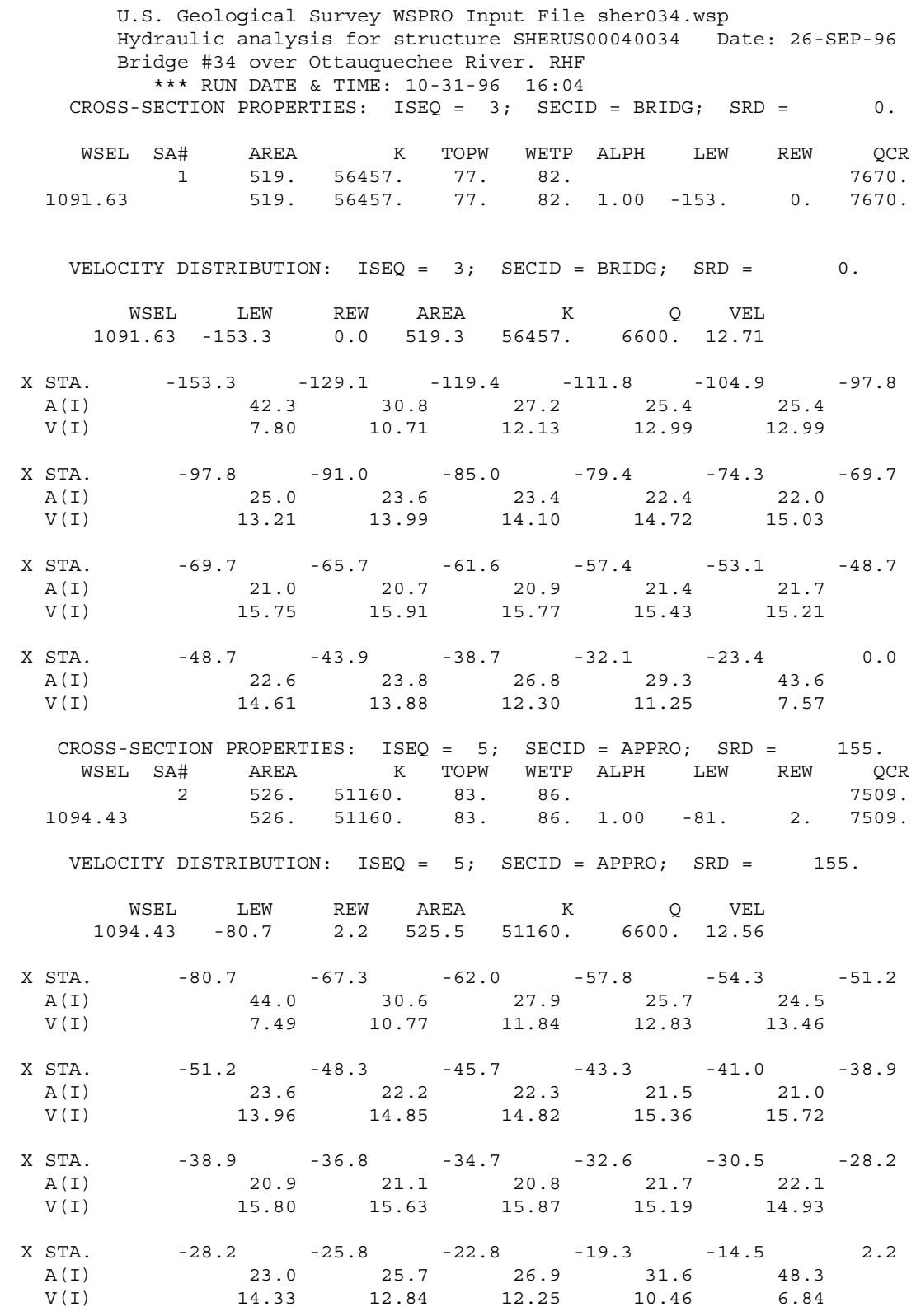


WSPRO OUTPUT FILE (continued)

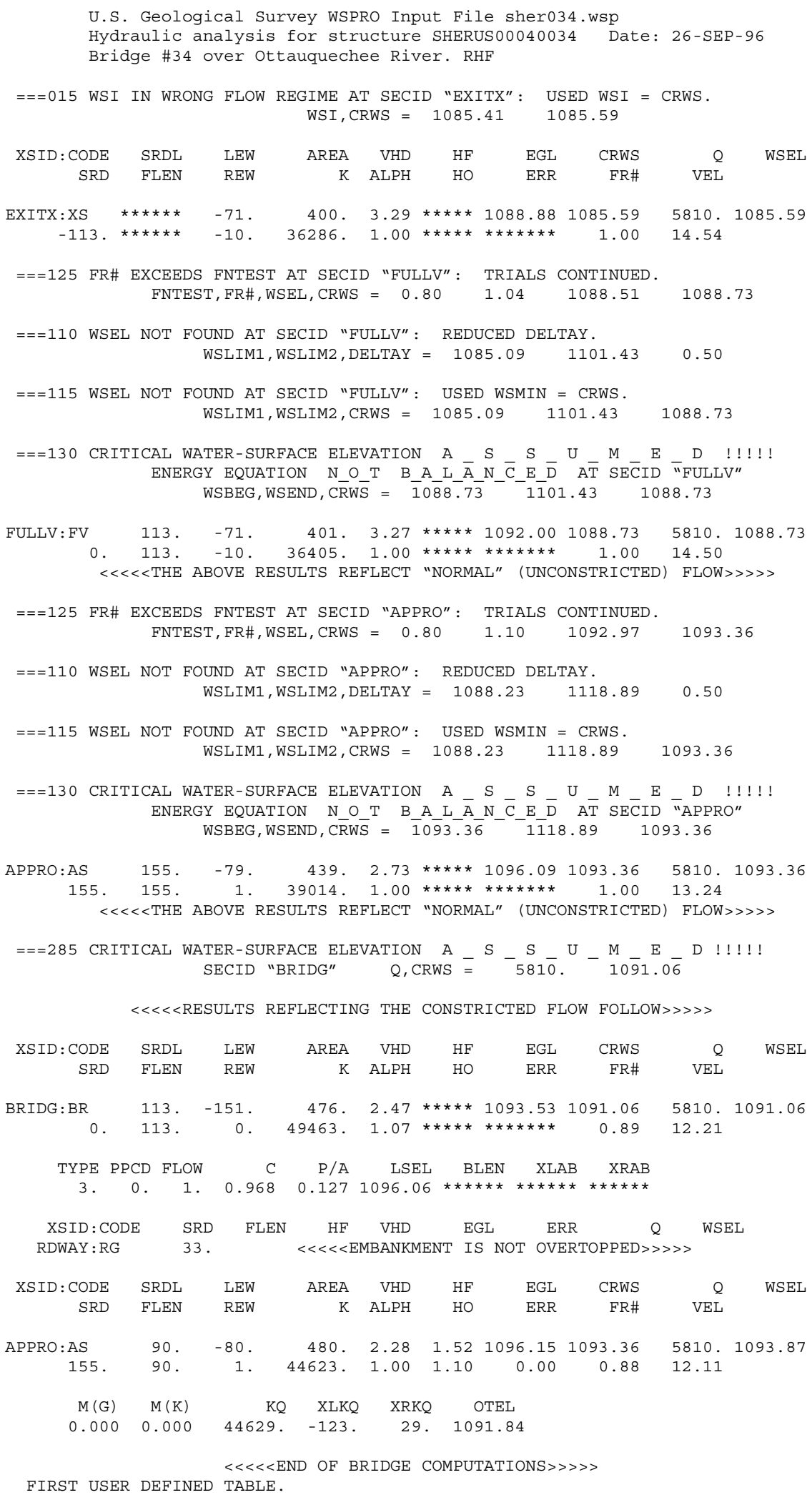




\section{WSPRO OUTPUT FILE (continued)}

SECOND USER DEFINED TABLE.

\begin{tabular}{|c|c|c|c|c|c|c|c|c|c|}
\hline XSID : CODE & CRWS & FR\# & YMIN & YMAX & $\mathrm{HF}$ & $\mathrm{HO}$ & VHD & EGL & \\
\hline EXITX:XS & 1085.59 & 1.00 & 1075.99 & $1098.31 *$ & 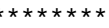 & $* \star \star \star \star *$ & 3.29 & 1088.88 & \\
\hline ULLV : FV & 1088.73 & .00 & 079.11 & $01.43 *$ & 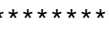 & & 3.27 & 1092.00 & 108 \\
\hline & 091.06 & 0.89 & 1081.34 & * & 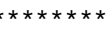 & $\star \star \star \star \star *$ & 2.47 & 1093.53 & 10 \\
\hline & 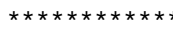 & $\star \star \star \star * *$ & & & 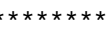 & & & & \\
\hline $0: A$ & 1093.36 & 0.88 & 1084.21 & 118.89 & 1.52 & 1.10 & 2.28 & 1096.15 & \\
\hline
\end{tabular}


WSPRO OUTPUT FILE (continued)

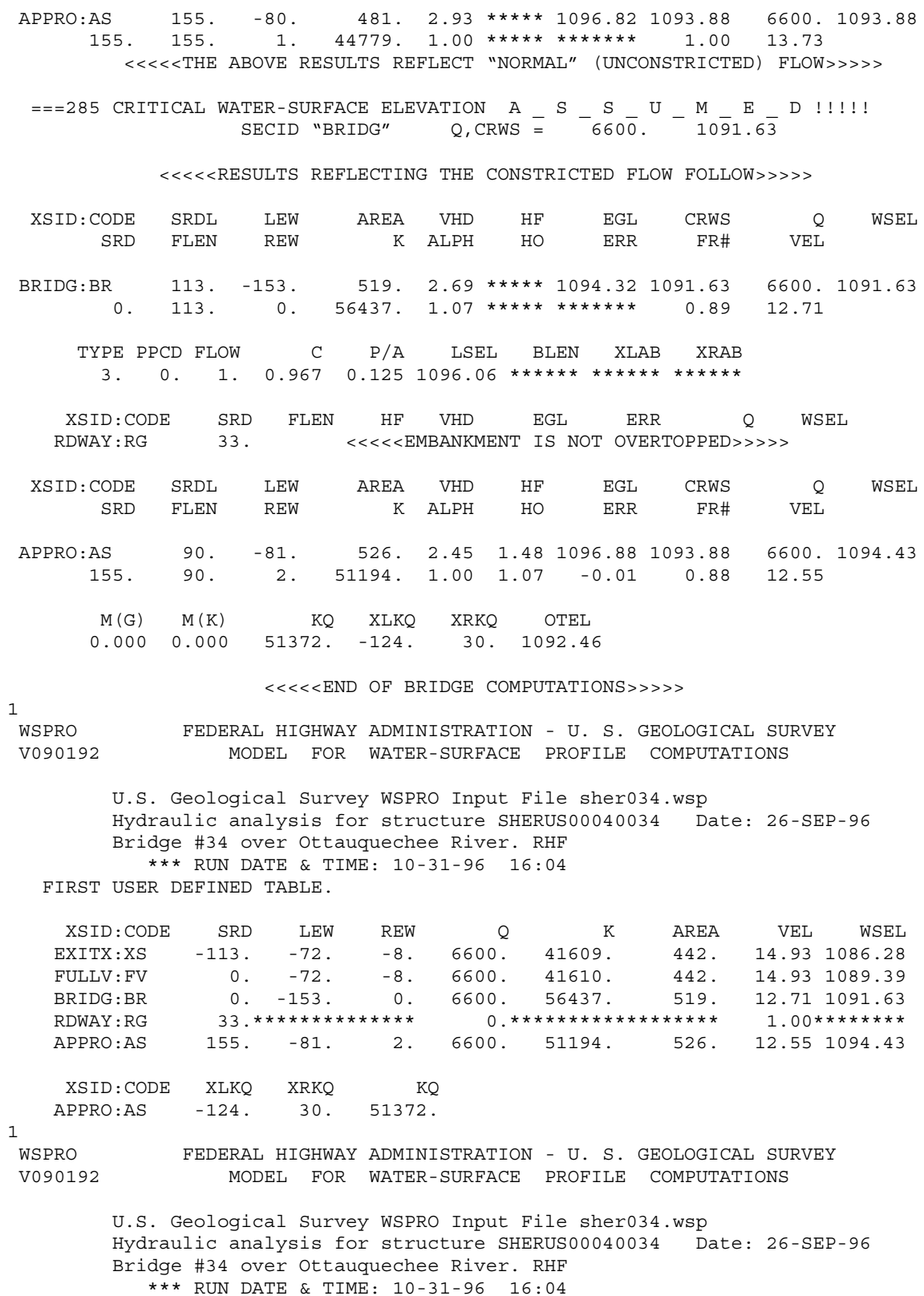




\section{APPENDIX C:}

\section{BED-MATERIAL PARTICAL-SIZE DISTRIBUTION}




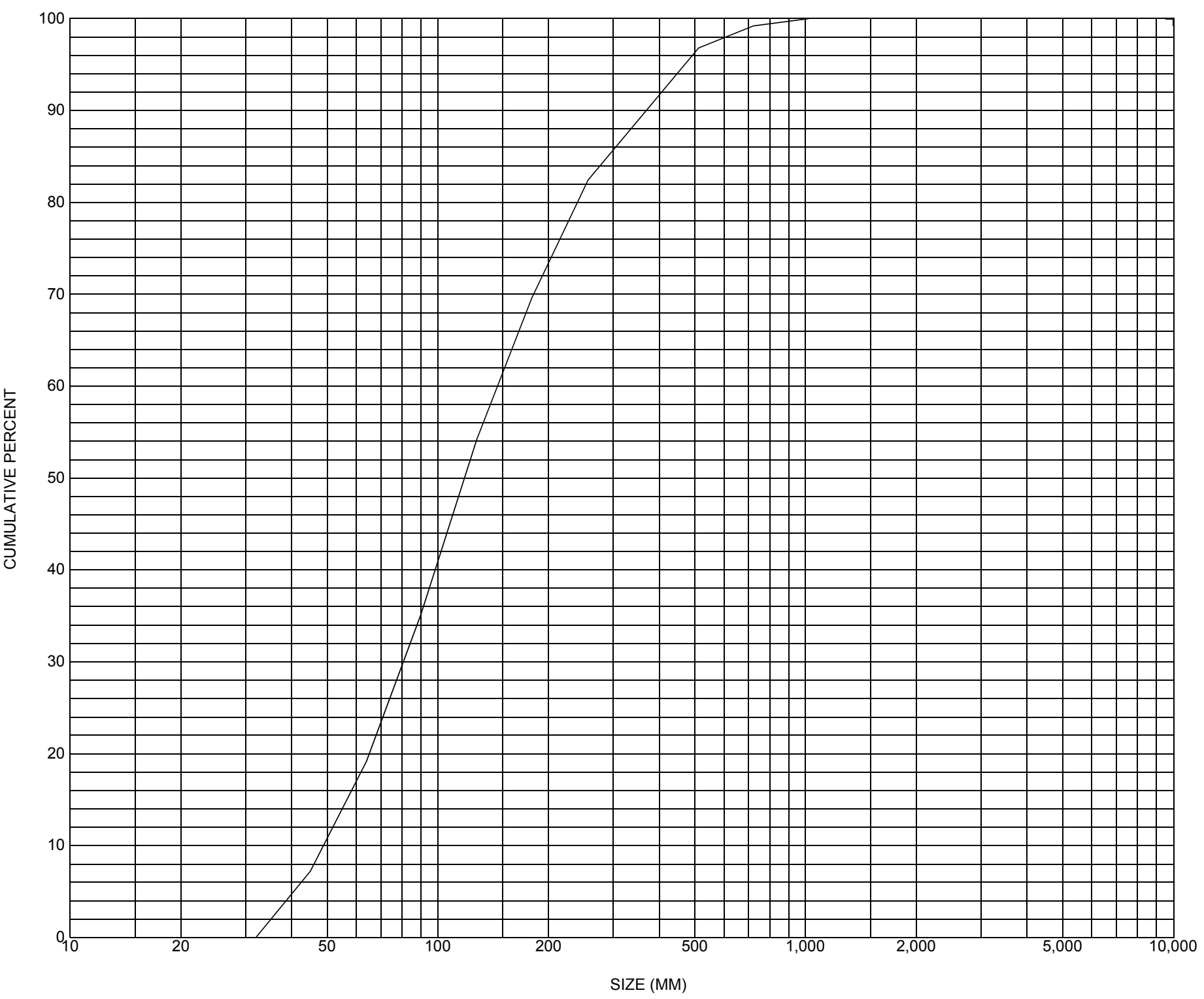

Appendix C. Bed material particle-size distribution for a pebble count in the channel approach of structure SHERUS00040034, in Sherburne, Vermont. 


\section{APPENDIX D: \\ HISTORICAL DATA FORM}




\section{Structure Number SHERUS00040034}

\section{General Location Descriptive}

Data collected by (First Initial, Full last name) $\mathbf{E}$. BOEHMLER

Date $(M M / D D / Y Y) \_\mathbf{0 3} / \underline{14} / \underline{95}$

Highway District Number (I - 2; nn) $\mathbf{0 3}$

Town (FIPS place code; I - 4; nnnnn) $\mathbf{6 4 8 2 5}$

Waterway (I - 6) OTTAUQUECHEE RIVER

Route Number US004

Topographic Map Killington Peak

Latitude (I - 16; nnnn.n) $\mathbf{4 3 3 6 4}$
County (FIPS county code; I - 3; nnn)

Mile marker (I - 11; nnn.nnn) $\mathbf{0 0 8 2 4 0}$

Road Name (I - 7): -

Vicinity (I - 9) 0.3 MI W JCT. VT.100 S

Hydrologic Unit Code: $\mathbf{0 1 0 8 0 1 0 6}$

Longitude (i - 17; nnnnn.n) $\mathbf{7 2 4 5 0}$

\section{Select Federal Inventory Codes}

FHWA Structure Number $(I-8) \underline{\mathbf{2 0 0 0 2 0 0 0 3 4 1 1 2 1}}$

Maintenance responsibility $(I-21 ; n n) \quad \mathbf{0 1} \quad$ Maximum span length $(I-48 ; n n n n) \underline{\mathbf{0 0 7 5}}$

Year built (I - 27; YYYY) 1961

Structure length (I - 49; nnnnnn) $\underline{\mathbf{0 0 0 1 8 7}}$

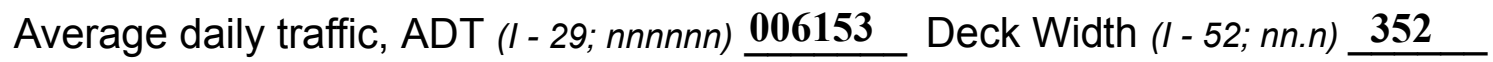

Year of ADT (I-30; YY) $\mathbf{9 2}$

Channel \& Protection $(I-61 ; n) \underline{\mathbf{8}}$

Opening skew to Roadway $(I-34 ; n n) \quad \mathbf{6 0}$

Waterway adequacy $(I-71 ; n) \underline{8}$

Operational status $(I-41 ; X) \quad \mathbf{A}$

Underwater Inspection Frequency $(I-92 B ; X Y Y) \_\mathbf{N}$

Structure type (I- 43; nnn) $\mathbf{3 0 2}$

Year Reconstructed (I - 106) 1991

Approach span structure type (I - 44; nnn) $\mathbf{0 0 0}$

Clear span (nnn.n ft) $\quad \mathbf{0 4 0 . 8}$

Number of spans (I - 45; nnn) $\underline{\mathbf{0 0 3}}$

Vertical clearance from streambed (nnn.n ft) $\underline{\mathbf{0 1 4 . 0}}$

Number of approach spans $(I-46 ; n n n n) \underline{\mathbf{0 0 0 0}}$ Waterway of full opening $\left(n n n . n f^{2}\right) \underline{\mathbf{5 7 0 . 0}}$

Comments:

The structural inspection report of 10/8/93 indicates the structure is a three span rolled steel beam type bridge. The left abutment wall is reported as having some minor cracking. The left pier has areas of cracking. The right pier (\#2) has some concrete cracking and a small area of spalling. The right abutment wall, like the left, has some minor cracking and scaling noted. Both abutments are protected with heavy stone fill (riprap). The channel proceeds straight through the bridge with the predominant flow through the middle span (\#2). The channel bed is reported as being composed of boulders and bed rock. Vegetation is noted as growing on the embankments both up and downstream. 


\section{Bridge Hydrologic Data}

Is there hydrologic data available? $\mathbf{N}$ if No, type ctrl- $n$ VTAOT Drainage area $\left(\mathrm{mi}^{2}\right)^{2}$ : -

Terrain character: Hilly

Stream character \& type: .

Streambed material: Boulders and bedrock

Discharge Data (cfs): $\quad Q_{2.33}$

$$
\mathrm{Q}_{50}
$$

Record flood date (MM / DD / YY): -

Estimated Discharge (cfs): I

$\mathrm{Q}_{10}-$

$\mathrm{Q}_{25}-$

Water surface elevation $(f t):-$

Ice conditions (Heavy, Moderate, Light) : light

Velocity at $Q$ $(\mathrm{ft} / \mathrm{s}):$

The stage increases to maximum highwater elevation (Rapidly, Not rapidly): Not rapidly

The stream response is (Flashy, Not flashy): Not flashy

Describe any significant site conditions upstream or downstream that may influence the stream's stage: -

Watershed storage area (in percent):

The watershed storage area is: - _ (1-mainly at the headwaters; 2- uniformly distributed; 3-immediatly upstream oi the site)

Water Surface Elevation Estimates for Existing Structure:

\begin{tabular}{|l|l|l|l|l|l|}
\hline Peak discharge frequency & $Q_{2.33}$ & $Q_{10}$ & $Q_{25}$ & $Q_{50}$ & $Q_{100}$ \\
Water surface elevation (ft)) & - & - & - & - & - \\
Velocity (ft/sec) & - & - & - & - & - \\
\hline
\end{tabular}

Long term stream bed changes: -

Is the roadway overtopped below the $\mathrm{Q}_{100}$ ? (Yes, No, Unknown): $\mathbf{U} \quad$ Frequency: -

Relief Elevation $(f t)$ :

Discharge over roadway at $Q_{100}\left(f^{3} / \mathrm{sec}\right)$ :

Are there other structures nearby? (Yes, No, Unknown): Upstream distance (miles): Town: If No or Unknown, type ctrl-n os Highway No. : Structure No. : Year Built:

Clear span (ft): Clear Height (ft): Full Waterway $\left(f t^{2}\right)$ : 
Downstream distance (miles): Town: Year Built:

Highway No. : Structure No. : Structure Type:

Clear span (ft): Clear Height $(f t)$ : Full Waterway $\left(f^{2}\right)$ :

Comments:

Some hydrologic information is printed on the plans which is shown above. The plans also show a drainage area equal to 17,538 acres.

\section{USGS Watershed Data}

Watershed Hydrographic Data

Drainage area $(D A) \underline{\mathbf{2 5 . 8 4 5}} \mathrm{mi}^{2}$ Lake and pond area $\underline{\mathbf{0 . 3 8 5}}$ $\mathrm{mi}^{2}$

Watershed storage (ST)

Bridge site elevation 1090 1.49 $\%$

Main channel length 10.473 $\mathrm{ft}$

Headwater elevation 2782 $\mathrm{ft}$ $10 \%$ channel length elevation $\mathbf{1 1 3 5}$ $\mathrm{ft} \quad 85 \%$ channel length elevation 1472 $\mathrm{ft}$

Main channel slope (S) 42.9 $\mathrm{ft} / \mathrm{mi}$

Watershed Precipitation Data

Average site precipitation in Average headwater precipitation in

Maximum 2yr-24hr precipitation event $(124,2)$ in

Average seasonal snowfall (Sn) _$\mathrm{ft}$ 


\section{Bridge Plan Data}

Are plans available? $\underline{\mathbf{Y}}$ If no, type ctrl-n pl Date issued for construction (MM/YYYY): $\underline{\mathbf{0 8}} / \mathbf{1 9 5 8}$ Project Number F 020-2(2) Minimum channel bed elevation: $\mathbf{1 0 8 0 . 5}$

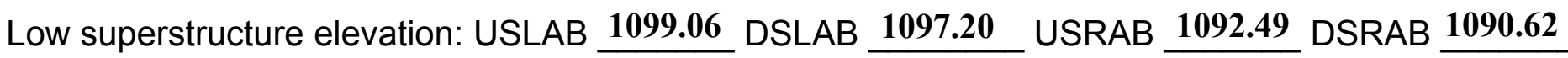
Benchmark location description:

No benchmark information is provided on the plans. However, a couple points shown with elevations are: 1) the highest of three concrete step-like posts at the upstream end of the left abutment on the streamward edge midway across the post width, elevation 1107.08, and 2) the point at the same location as in (1) but on the upstream right abutment side, elevation 1100.67.

Reference Point (MSL, Arbitrary, Other): MSL $\quad$ Datum (NAD27, NAD83, Other): NGVD1929 Foundation Type: 1

If 1: Footing Thickness 3.0 Footing bottom elevation: 1086.*

If 2: Pile Type: __ (1-Wood; 2-Steel or metal; 3-Concrete) Approximate pile driven length:

If 3: Footing bottom elevation:

Is boring information available? $\quad \mathbf{Y}$ If no, type ctrl-n bi Number of borings taken: $\underline{4}$

Foundation Material Type: 1 (1-regolith, 2-bedrock, 3-unknown)

Briefly describe material at foundation bottom elevation or around piles:

The left abutment is set in mainly a gravel and boulder material with some sand. The right abutment is set in gravel and stones. Both pier footings are set in hard, compact gravel with some sand.

Comments:

*Footing bottom elevation left: 1090.0 and right: 1086.0. The plans show a flow through abutment type. The footings on each abutment wall are only 2.0 feet thick while those on the piers are 3.0 feet thick. The bottom of the footing on each pier is shown at 1072.0 feet AMSL. The low superstructure elevations for the piers: pier 1(left) upstream end 1097.27(left), 1096.65(right) downstream end 1095.40(left), 1094.78(right); pier 2(right) upstream end 1094.08(left), 1094.29(right) downstream end 1092.21(left), 1092.42(right). The piers are 53 feet long and 4 feet wide. 


\section{Cross-sectional Data}

Is cross-sectional data available? $\mathbf{N}$ If no, type ctrl-n xs

Source (FEMA, VTAOT, Other)? -

Comments: NO CROSS SECTION INFORMATION

\begin{tabular}{|l|l|l|l|l|l|l|l|l|l|l|l|}
\hline Station & - & - & - & - & - & - & - & - & - & - & - \\
\hline Feature & - & - & - & - & - & - & - & - & - & - & - \\
\hline $\begin{array}{l}\text { Low cord } \\
\text { elevation }\end{array}$ & - & - & - & - & - & - & - & - & - & - & - \\
\hline $\begin{array}{l}\text { Bed } \\
\text { elevation }\end{array}$ & - & - & - & - & - & - & - & - & - & - & - \\
\hline $\begin{array}{l}\text { Low cord to } \\
\text { bed length }\end{array}$ & - & - & - & - & - & - & - & - & - & - & - \\
\hline Station & - & - & - & - & - & - & - & - & - & - & - \\
\hline Feature & - & - & - & - & - & - & - & - & - & - & - \\
\hline $\begin{array}{l}\text { Low cord } \\
\text { elevation }\end{array}$ & - & - & - & - & - & - & - & - & - & - & - \\
\hline $\begin{array}{l}\text { Bed } \\
\text { elevation }\end{array}$ & - & - & - & - & - & - & - & - & - & - & - \\
\hline $\begin{array}{l}\text { Low cord to } \\
\text { bed length }\end{array}$ & - & - & - & - & - & - & - & - & - & - & - \\
\hline
\end{tabular}

Source (FEMA, VTAOT, Other)?

Comments: NO CROSS SECTION INFORMATION

\begin{tabular}{|l|l|l|l|l|l|l|l|l|l|l|l|}
\hline Station & - & - & - & - & - & - & - & - & - & - & - \\
\hline Feature & - & - & - & - & - & - & - & - & - & - & - \\
\hline $\begin{array}{l}\text { Low cord } \\
\text { elevation }\end{array}$ & - & - & - & - & - & - & - & - & - & - & - \\
\hline $\begin{array}{l}\text { Bed } \\
\text { elevation }\end{array}$ & - & - & - & - & - & - & - & - & - & - & - \\
\hline $\begin{array}{l}\text { Low cord to } \\
\text { bed length }\end{array}$ & - & - & - & - & - & - & - & - & - & - & - \\
\hline Station & - & - & - & - & - & - & - & - & - & - & - \\
\hline Feature & - & - & - & - & - & - & - & - & - & - & - \\
\hline $\begin{array}{l}\text { Low cord } \\
\text { elevation }\end{array}$ & - & - & - & - & - & - & - & - & - & - & - \\
\hline $\begin{array}{l}\text { Bed } \\
\text { elevation }\end{array}$ & - & - & - & - & - & - & - & - & - & - & - \\
\hline $\begin{array}{l}\text { Low cord to } \\
\text { bed length }\end{array}$ & - & - & - & - & - & - & - & - & - & - & - \\
\hline
\end{tabular}




\section{APPENDIX E: \\ LEVEL I DATA FORM}




\section{Structure Number SHERUS00040034}

Computerized by: $\underline{\mathbf{R B}}$ Date: $2 / 20 / 96$

Reviewd by: $\quad$ RF Date: $\underline{10 / 17 / 96}$

\section{A. General Location Descriptive}

\section{Data collected by (First Initial, Full last name) T . SEVERANCE}

Date $(M M / D D / Y Y)$

2. Highway District Number $\mathbf{3}$

County RUTLAND 021

Waterway (I - 6)

Route Number US0004
Mile marker $\mathbf{0 0 8 2 4 0}$

Town SHERBURNE 64825

Road Name -

Hydrologic Unit Code: $\mathbf{0 1 0 8 0 1 0 6}$

3. Descriptive comments:

.3 MI with junction VT 100S. Just west of the Bridgewater border and junction with VT 100, (VT100 and US4 run together here and go N/W). The Hadley Hill Road intersection is just $\mathrm{S} / \mathrm{E}$ of the bridge and the Johnson Road intersection is just N/W of the bridge. There are two piers and all the flow is between them at this time. The bridge is made of steel beams with a concrete deck and asphalt top. There is granite / concrete curbing with steel rail.

\section{B. Bridge Deck Observations}
4. Surface cover... LBUS 6
RBUS 6
LBDS 65
RBDS 6
Overall 6

(2b us,ds,lb,rb: 1- Urban; 2- Suburban; 3- Row crops; 4- Pasture; 5- Shrub- and brushland; 6- Forest; 7- Wetland)
5. Ambient water surface... US 2
UB 2
DS $\underline{2}$
(1- pool; 2- riffle)

6. Bridge structure type 2 (1- single span; 2- multiple span; 3- single arch; 4- multiple arch; 5-cylindrical culvert; 6- box culvert; or 7- other)
7. Bridge length 187
(feet)
Span length $\mathbf{2 2 5}$
(feet)
Bridge width 35.2 (feet)

\section{Road approach to bridge:}

\section{LB 1 RB 1 ( 0 even, 1- lower, 2- higher) \\ 9. LB 1 RB 1 (1-Paved, 2- Not paved)}

10. Embankment slope (run / rise in feet / foot):

US left

US right

\begin{tabular}{|c|c|c|c|c|}
\hline & \multicolumn{2}{|c|}{ Protection } & \multirow{2}{*}{ 13. Erosion } & \multirow{2}{*}{ 14.Severity } \\
\hline & 11.Type & 12.Cond. & & \\
\hline LBUS & 0 & - & 2 & 1 \\
\hline RBUS & $\mathbf{0}$ & - & $\mathbf{0}$ & - \\
\hline RBDS & $\mathbf{0}$ & - & $\mathbf{0}$ & - \\
\hline LBDS & $\mathbf{0}$ & - & 2 & 1 \\
\hline
\end{tabular}

Bank protection types: 0- none; 1- < 12 inches;

2- $<36$ inches; $3-<48$ inches;

4- < 60 inches; 5- wall / artificial levee

Bank protection conditions: 1- good; 2- slumped;

3- eroded; 4- failed

Erosion: 0 - none; 1- channel erosion; 2

road wash; 3- both; 4- other

Erosion Severity: 0 - none; 1- slight; 2- moderate; 3- severe

\section{Channel approach to bridge (BF):}

15. Angle of approach: $\mathbf{0}$

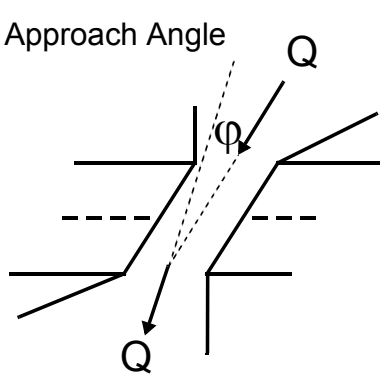

17. Channel impact zone 1 :

Where? $(L B, R B)$

Range? feet -

Channel impact zone 2:

Where? $(L B, R B)$

Range? - $\quad$ feet (US, UB, DS) to feet -

16. Bridge skew: 60 Bridge Skew Angle

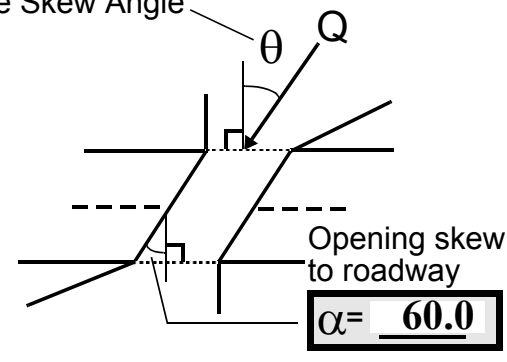

Exist? $\mathbf{N}(Y$ or $N)$

Severity (US, UB, DS) to feet -

Exist? $\mathbf{N}(Y$ or $N)$

Severity -

Impact Severity: 0- none to very slight; 1- Slight; 2- Moderate; 3- Severe 
18. Bridge Type: $\mathbf{1 b}$

1a- Vertical abutments with wingwalls

$1 \mathrm{~b}$ - Vertical abutments without wingwalls

2- Vertical abutments and wingwalls, sloping embankment

Wingwalls perpendicular to abut. face

3- Spill through abutments

4- Sloping embankment, vertical wingwalls and abutments

1a with wingwalls

Wingwall angle less than $90^{\circ}$.

19. Bridge Deck Comments (surface cover variations, measured bridge and span lengths, bridge type variations, approach overflow width, etc.)

7. Values are from the VT AOT.

Measured bridge length is 187 feet, span length is $\mathbf{1 8 7 . 3}$ feet, and bridge width is 35 feet

\section{Upstream Channel Assessment}

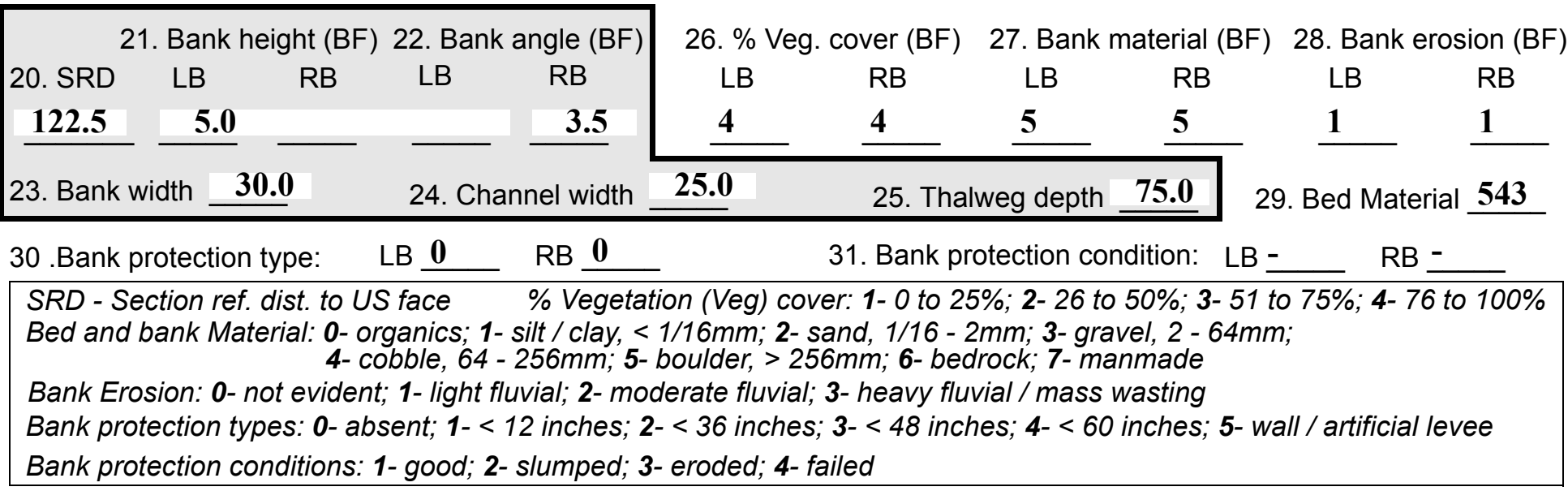

32. Comments (bank material variation, minor inflows, protection extent, etc.):

30. Boulders exist naturally along both banks.

There are some trees with exposed roots, boulders and cobbles have been left behind on the banks.

The stream is seperated US and rejoins 275 feet US. 
33.Point/Side bar present? $\mathbf{Y}$

$(Y$ or N. if $N$ type ctrl-n pb)34. Mid-bar distance: 87

35. Mid-bar width: 24

36. Point bar extent: 27 feet UB

(US, UB) to 155 feet $\underline{\mathbf{U S}}$

(US, UB, DS) positioned $\mathbf{0}$

$\%$ LB to $\mathbf{7 5}$ $\% \mathrm{RB}$

37. Material: $\mathbf{5 4 3}$

38. Point or side bar comments (Circle Point or Side; Note additional bars, material variation, status, etc.):

A small portion of the flow trickles over the bar at mid-bar and rejoins the main flow 15 feet DS.

39. Is a cut-bank present? $\mathbf{N}$ ( $Y$ or if $N$ type ctrl-n $c b)$

40. Where? - $(L B$ or $R B)$

41. Mid-bank distance: -

42. Cut bank extent: -

feet -

(US, UB) to feet (US, UB, DS)

43. Bank damage: -

(1- eroded and/or creep; 2- slip failure; 3- block failure)

44. Cut bank comments (eg. additional cut banks, protection condition, etc.):

NO CUT BANKS

45. Is channel scour present? $\mathbf{N}$ ( $Y$ or if $N$ type ctrl-n cs)

47. Scour dimensions: Length -

Width -

Depth : -

46. Mid-scour distance: -

48. Scour comments (eg. additional scour areas, local scouring process, etc.):

NO CHANNEL SCOUR

Some local scouring not due to bridge.

49. Are there major confluences? $\mathbf{Y}$ ( $Y$ or if $N$ type ctrl-n $m c)$

51. Confluence 1: Distance $>\mathbf{2 5 0}$

Confluence 2: Distance -

52. Enters on $\underline{\mathbf{R B}}$ (LB or $R B)$

Enters on (LB or $R B)$

54. Confluence comments (eg. confluence name):

Where the confluence enters it is the same width as our channel.
50. How many? 1

53. Type 1 (1- perennial; 2- ephemeral)

Type (1-perennial; 2- ephemeral)

\section{Under Bridge Channel Assessment}

55. Channel restraint (BF)? LB 2

56. Height (BF)
LB RB
$\mathbf{5 9 . 5}-$
58. Bank width (BF) -

59. Channel width (Amb)

(1- natural bank; 2- abutment; 3- artificial levee)

Bed and bank Material: 0- organics; 1- silt / clay, < 1/16mm; 2- sand, 1/16 - 2mm; 3- gravel, 2 - 64mm; 4- cobble, 64 - 256mm; 5- boulder, > 256mm; 6- bedrock; 7- manmade

Bank Erosion: 0- not evident; 1- light fluvial; 2- moderate fluvial; 3- heavy fluvial / mass wasting

64. Comments (bank material variation, minor inflows, protection extent, etc.):

45

All of the flow is currently passing between the piers. 
65. Debris and Ice Is there debris accumulation?

(Yor $N)$ 66. Where? $\mathbf{N}$

(1- Upstream; 2- At bridge; 3- Both)

67. Debris Potential ( 1- Low; 2- Moderate; 3- High)

68. Capture Efficiency 1 (1-Low; 2- Moderate; 3- High)

69. Is there evidence of ice build-up? 2 (Y or $N)$

Ice Blockage Potential $\mathbf{N}$

(1- Low; 2- Moderate; 3- High)

70. Debris and Ice Comments:

1

The channel is wide beneath the bridge, there is no debris at the US ends of the piers. Some debris (log) is on the US right bank lodged in/on the protection.

\begin{tabular}{|l|c|c|c|c|c|c|c|c|}
\hline Abutments & $\begin{array}{c}\text { 71. Attack } \\
\angle \text { (BF) }\end{array}$ & $\begin{array}{c}72 \text {. Slope } \angle \\
\text { (Qmax) }\end{array}$ & $\begin{array}{c}\text { 73. Toe } \\
\text { loc. (BF) }\end{array}$ & $\begin{array}{c}\text { 74. Scour } \\
\text { Condition }\end{array}$ & $\begin{array}{c}75 . \text { Scour } \\
\text { depth }\end{array}$ & $\begin{array}{c}\text { 76. Exposure } \\
\text { depth }\end{array}$ & 77. Material & 78. Length \\
\hline LABUT & & $\mathbf{0}$ & $\mathbf{9 0}$ & $\mathbf{0}$ & $\mathbf{0}$ & - & - & $\mathbf{9 0 . 0}$ \\
\hline RABUT & $\mathbf{1}$ & $\mathbf{0}$ & $\mathbf{9 0}$ & & & $\mathbf{0}$ & $\mathbf{0}$ & $\mathbf{8 9 . 5}$ \\
\hline
\end{tabular}

Pushed: $L B$ or RB

Toe Location (Loc.): 0- even, 1- set back, 2- protrudes

Scour cond.: 0- not evident; 1- evident (comment); 2- footing exposed; 3-undermined footing; 4- piling exposed; 5- settled; 6- failed

Materials: 1- Concrete; 2- Stone masonry or drywall; 3- steel or metal; 4- wood

79. Abutment comments (eg. undermined penetration, unusual scour processes, debris, etc.):

-

1

72. There is a 45 degree slope angle of the stone fill which is piled to within 2 feet of the steel on both abutments.

80. Wingwalls: $\begin{array}{lllll} & & & & \\ \text { Exist? } & & & \\ & & & & \\ & \text { Condition? } & \text { depth? } & \text { depth? }\end{array}$

USLWW:

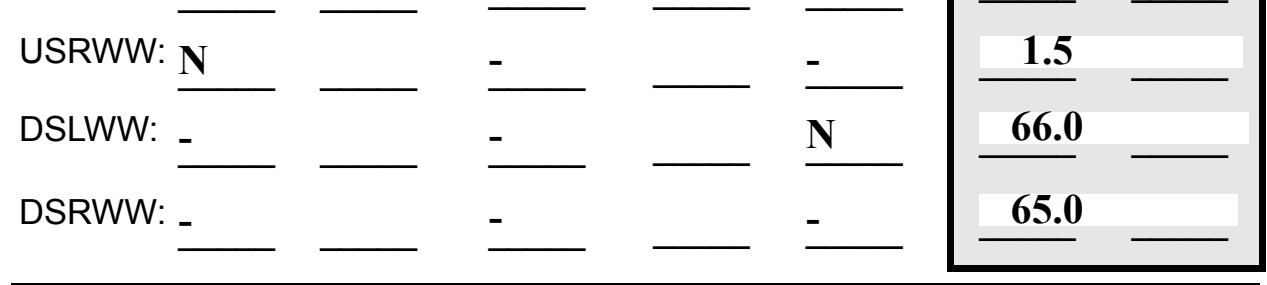

Wingwall materials: 1- Concrete; 2- Stone masonry or drywall; 3- steel or metal; 4- wood

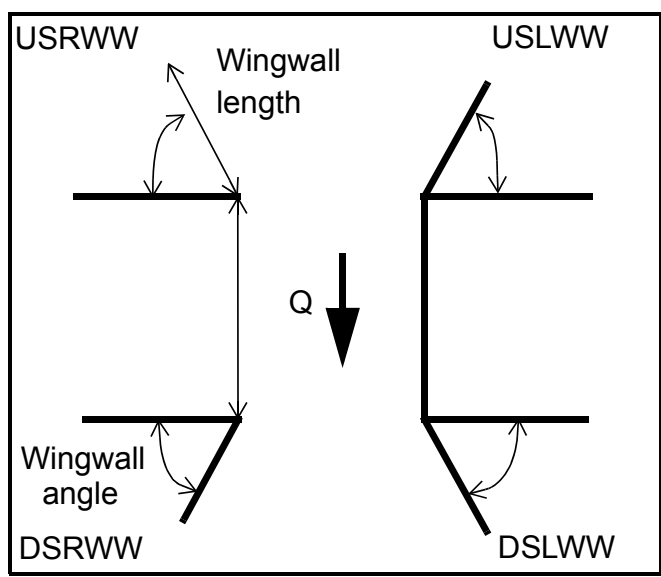

82. Bank / Bridge Protection:

\begin{tabular}{|l|l|l|l|l|l|l|l|c|}
\hline Location & USLWW & USRWW & LABUT & RABUT & LB & RB & DSLWW & DSRWW \\
\hline Type & - & - & $\mathbf{N}$ & - & - & - & $\mathbf{1}$ & $\mathbf{1}$ \\
\hline Condition & $\mathbf{N}$ & - & - & - & - & - & $\mathbf{1}$ & $\mathbf{1}$ \\
\hline Extent & - & - & - & - & - & $\mathbf{3}$ & $\mathbf{3}$ & - \\
\hline
\end{tabular}

Bank / Bridge protection types: 0- absent; 1- < 12 inches; 2- < 36 inches; 3- < 48 inches; 4- < 60 inches; 
83. Wingwall and protection comments (eg. undermined penetration, unusual scour processes, etc.):

-
-
-
-
-
-
-
-
-

\section{Piers:}

84. Are there piers? Co (Y or if $N$ type ctrl-n pr)

\begin{tabular}{|l|l|l|l|l|l|l|l|}
\hline \multirow{2}{*}{$\begin{array}{l}85 . \\
\text { Pier no. }\end{array}$} & \multicolumn{3}{|c|}{ width (w) feet } & \multicolumn{3}{c|}{ elevation (e) feet } \\
\cline { 2 - 9 } & w1 & w2 & w3 & e@w1 & e@w2 & e@w3 \\
\hline Pier 1 & - & - & - & - & - & - \\
\hline Pier 2 & - & - & - & - & - & - \\
\hline Pier 3 & - & - & - & - & - & - \\
\hline Pier 4 & - & - & - & - & - & - \\
\hline
\end{tabular}

\begin{tabular}{|l|l|l|l|l|}
\hline Level 1 Pier Descr. & \multicolumn{1}{|c|}{1} & \multicolumn{1}{|c|}{2} & \multicolumn{1}{|c|}{3} & \multicolumn{1}{|c|}{4} \\
\hline 86. Location (BF) & ncret & piled & With & is the \\
\hline 87. Type & e & at & in & rema \\
\hline 88. Material & wing & the & half & ins \\
\hline 89. Shape & walls & four & a & of an \\
\hline 90. Inclined? & do & cor- & brid & old \\
\hline 91. Attack $\angle$ (BF) & not & ners & ge & abut \\
\hline 92. Pushed & exist, & wher & lengt & ment \\
\hline 93. Length (feet) & - & - & - & - \\
\hline 94. \# of piles & but & e the & h on & - \\
\hline 95. Cross-members & there & wing & the & Ther \\
\hline 96. Scour Condition & is & walls & DS & e is \\
\hline 97. Scour depth & stone & woul & left & stone \\
\hline 98. Exposure depth & fill & d be. & bank & fill \\
\hline
\end{tabular}

LFP, LTB, LB, MCL, MCM, MCR, RB, RTB, RFP

1- Solid pier, 2-column, 3- bent

1-Wood; 2-concrete; 3- metal; 4- stone

1- Round; 2- Square; 3- Pointed

Y-yes; $N-$ no

$L B$ or $R B$

0- none; 1- laterals; 2- diagonals; 3- both

0- not evident; 1- evident (comment);

2- footing exposed; 3- piling exposed;

4- undermined footing; 5- settled; 6- failed 
99. Pier comments (eg. undermined penetration, protection and protection extent, unusual scour processes, etc.): piled between this abutment and the bridge.

$\mathbf{Y}$

100.

\section{E. Downstream Channel Assessment}

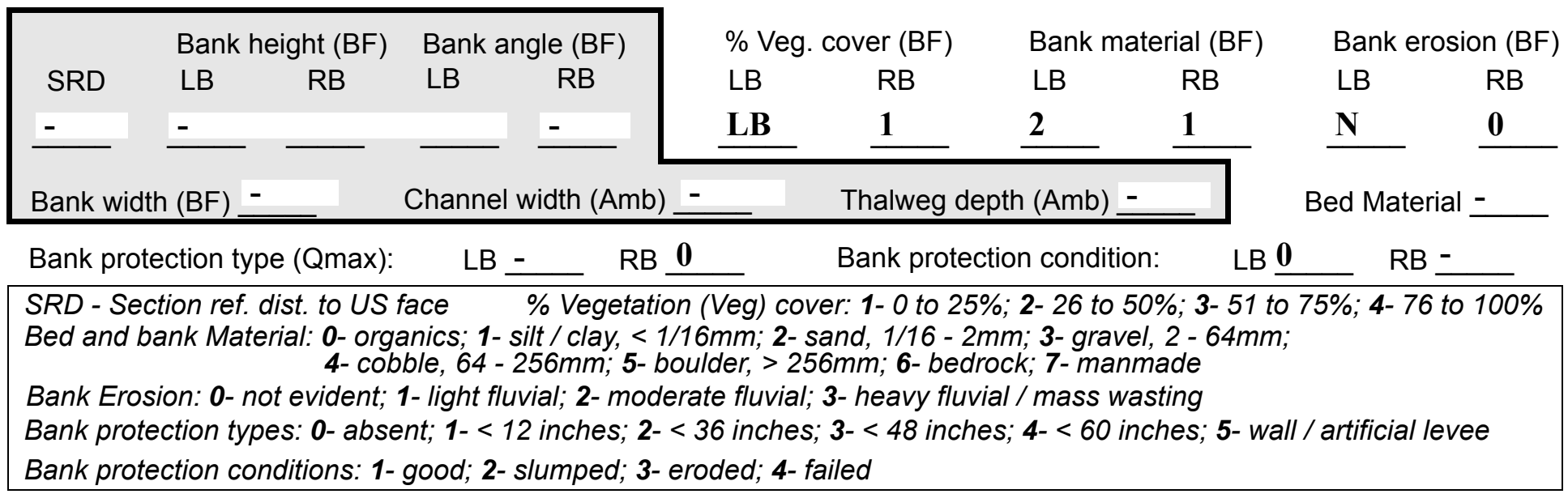

Comments (eg. bank material variation, minor inflows, protection extent, etc.):

-

RB

1

2

1

$\mathbf{N}$

O

$-$

$-$

$\mathbf{0}$

0

$-$

$-$

$-$

$-$

101. Is a drop structure present? _ ( $Y$ or $N$, if $N$ type ctrl-n ds) 102. Distance: ___ feet
103. Drop: - feet
104. Structure material: -
(1- steel sheet pile; 2- wood pile; 3- concrete; 4- other)

105. Drop structure comments (eg. downstream scour depth): 

feet (US, UB, DS) to feet (US, UB, DS) positioned $\%$ LB to $\%$ RB Material:

Point or side bar comments (Circle Point or Side; note additional bars, material variation, status, etc.):

$-$

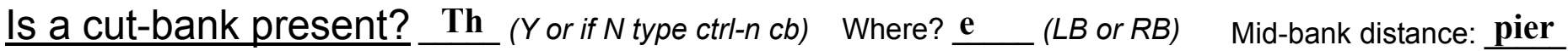
Cut bank extent: $\underline{\mathbf{s}}$ feet con (US, UB, DS) to sist feet of $\mathbf{3}$ (US, UB, DS)

Bank damage: col- (1- eroded and/or creep; 2- slip failure; 3- block failure)

Cut bank comments (eg. additional cut banks, protection condition, etc.):

umns each. Between the columns, walls have been poured. No scour is evident at the piers. The left pier is on the bankward side of the left bank point bar (previously described). Some water is pooled around the US end of the right pier but it does not travel through, all the flow passes along the left side of the right pier. Gravel, cobble, and several boulders line the streamward side of the right pier.

Is channel scour present? ( $Y$ or if $N$ type ctrl-n cs)

Mid-scour distance:

Scour dimensions: Length Width Depth:

Positioned $\%$ LB to $\underline{2} \%$ RB

Scour comments (eg. additional scour areas, local scouring process, etc.):

3

54

54

1

Are there major confluences? 1 ( 1 or if $N$ type ctrl-n $m c)$

Confluence 1: Distance $\mathbf{0}$ Enters on $\underline{\mathbf{0}}$ (LB or $R B)$

How many? 543

Confluence 2: Distance Enters on Wit $(L B$ or $R B)$

Type (1- perennial; 2- ephemeral)

Confluence comments (eg. confluence name):

1 bridge length there is stone fill along the right bank where the wingwall would be and an old abutment on the left bank. There is a narrow point bar along the right bank and minor cut bank along the left bank with

\section{F. Geomorphic Channel Assessment}

107. Stage of reach evolution tre

1- Constructed

2- Stable

3- Aggraded

4- Degraded

5- Laterally unstable

6- Vertically and laterally unstable 
108. Evolution comments (Channel evolution not considering bridge effects; See HEC-20, Figure 1 for geomorphic descriptors):

e roots exposed. There is a lot of cobble and boulders left behind on both DS banks, just as with the US banks. 


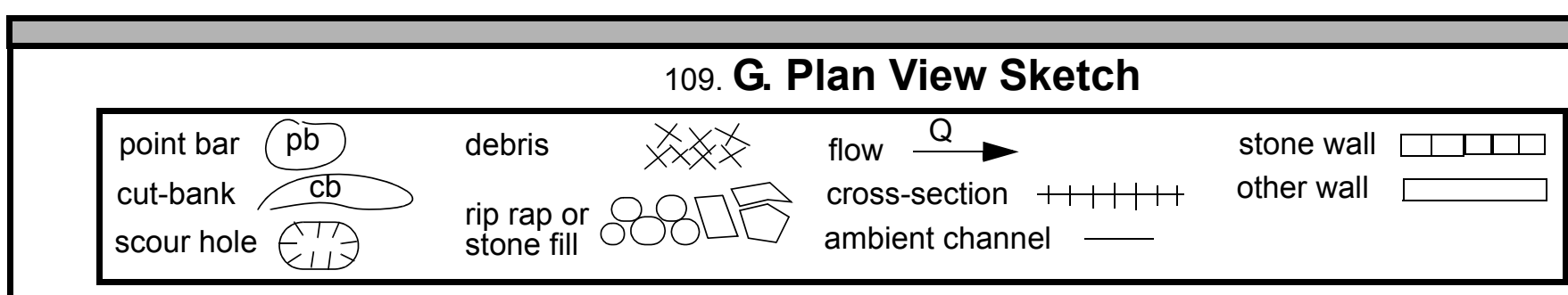


APPENDIX F:

SCOUR COMPUTATIONS 
SCOUR COMPUTATIONS

\begin{tabular}{|c|c|c|c|}
\hline $\begin{array}{l}\text { Structure Number: SHERUS00040034 } \\
\text { Road Number: } \\
\text { Stream: }\end{array}$ & & $\begin{array}{l}\text { Town: } \\
\text { County: }\end{array}$ & $\begin{array}{l}\text { SHERBURNE } \\
\text { RUTLAND }\end{array}$ \\
\hline Initials RF & Checked & SAO & \\
\hline Analysis of contraction scour, live & -bed or & lear wat & \\
\hline $\begin{array}{l}\text { Critical Velocity of Bed Material } \\
\text { VC=11.21*y } 1^{\wedge} 0.1667 * \mathrm{D} 50^{\wedge} 0.33 \text { with Ss } \\
\text { (Richardson and others, } 1995, \mathrm{p} .28\end{array}$ & $\begin{array}{l}\text { converte } \\
=2.65 \\
\text { eq. } 16\end{array}$ & to Engl & sh units) \\
\hline Approach Section & & & \\
\hline Characteristic & $100 \mathrm{yr}$ & $500 \mathrm{yr}$ & other $\mathrm{Q}$ \\
\hline Total discharge, cfs & 5810 & 8800 & 6600 \\
\hline Main Channel Area, ft2 & 479.6 & 833.8 & 525.5 \\
\hline Left overbank area, ft2 & 0 & 0 & 0 \\
\hline Right overbank area, ft2 & 0 & 0 & 0 \\
\hline Top width main channel, ft & 81.2 & 93.4 & 82.9 \\
\hline Top width L overbank, ft & 0 & 0 & 0 \\
\hline Top width $\mathrm{R}$ overbank, ft & 0 & 0 & 0 \\
\hline D50 of channel, ft & 0.3874 & 0.3874 & 0.3874 \\
\hline D50 left overbank, ft & 0 & 0 & 0 \\
\hline D50 right overbank, ft & 0 & 0 & 0 \\
\hline Y1, average depth, MC, ft & 5.9 & 8.9 & 6.3 \\
\hline $\mathrm{y}_{1}$, average depth, LOB, ft & ERR & ERR & ERR \\
\hline$y 1$, average depth, ROB, ft & ERR & ERR & ERR \\
\hline Total conveyance, approach & 44611 & 100830 & 51160 \\
\hline Conveyance, main channel & 44611 & 100830 & 51160 \\
\hline Conveyance, LOB & 0 & 0 & 0 \\
\hline Conveyance, ROB & 0 & 0 & 0 \\
\hline Percent discrepancy, conveyance & 0.0000 & 0.0000 & 0.0000 \\
\hline Qm, discharge, $\mathrm{MC}$, cfs & 5810.0 & 8800.0 & 6600.0 \\
\hline Q1, discharge, LOB, Cfs & 0.0 & 0.0 & 0.0 \\
\hline Qr, discharge, ROB, cfs & 0.0 & 0.0 & 0.0 \\
\hline $\mathrm{Vm}$, mean velocity $\mathrm{MC}$, ft/s & 12.1 & 10.6 & 12.6 \\
\hline VI, mean velocity, LOB, ft/s & ERR & ERR & ERR \\
\hline Vr, mean velocity, $\mathrm{ROB}, \mathrm{ft} / \mathrm{s}$ & ERR & ERR & ERR \\
\hline Vc-m, crit. velocity, MC, ft/s & 11.0 & 11.8 & 11.1 \\
\hline Vc-1, crit. velocity, LOB, ft/s & $\mathrm{N} / \mathrm{A}$ & $\mathrm{N} / \mathrm{A}$ & $\mathrm{N} / \mathrm{A}$ \\
\hline Vc-r, crit. velocity, ROB, ft/s & $\mathrm{N} / \mathrm{A}$ & $\mathrm{N} / \mathrm{A}$ & $\mathrm{N} / \mathrm{A}$ \\
\hline Results & & & \\
\hline Live-bed(1) or Clear-Water(0) Contr & action $\mathrm{S}$ & our? & \\
\hline Main Channel & 1 & 0 & 1 \\
\hline Left Overbank & $\mathrm{N} / \mathrm{A}$ & $\mathrm{N} / \mathrm{A}$ & $\mathrm{N} / \mathrm{A}$ \\
\hline Right Overbank & $\mathrm{N} / \mathrm{A}$ & $\mathrm{N} / \mathrm{A}$ & $\mathrm{N} / \mathrm{A}$ \\
\hline
\end{tabular}

Live-Bed Contraction Scour

Laursen's Live Bed Contraction Scour $\mathrm{y} 2 / \mathrm{Y} 1=(\mathrm{Q} 2 / \mathrm{Q} 1)^{\wedge}(6 / 7) *(\mathrm{~W} 1 / \mathrm{W} 2)^{\wedge}(\mathrm{k} 1)$

ys $=y^{2}-y_{-}$bridge

(Richardson and others, 1995, p. 30, eq. 17 and 18)

Characteristic

Q1, discharge, cfs Total conveyance Main channel conveyance Main channel discharge

Area - main channel, ft2

(W1) channel width, ft

(Wp) cumulative pier width, ft

W1, adjusted bottom width(ft) D50, ft

w, fall velocity, ft/s (p. 32)

$y$, ave. depth flow, ft

S1, slope EGI

$P$, wetted perimeter, $M C$, ft

$R$, hydraulic Radius, ft
Approach

$100 \mathrm{yr} 500 \mathrm{yr}$ Bridge

$\begin{array}{llllll}5810 & 8800 & 6600 & 5810 & 6047 & 6600\end{array}$

$\begin{array}{llllll}44611 & 100830 & 51160 & 49472 & 81229 & 56457\end{array}$

$\begin{array}{llllll}44611 & 100830 & 51160 & 49472 & 81229 & 56457\end{array}$

$5810-8800-6600-5810-6047$

$\begin{array}{llllll}479.6 & 833.8 & 525.5 & 475.8 & 801.8 & 519.3\end{array}$

$\begin{array}{llllll}81.2 & 93.4 & 82.9 & 75.75 & 88.05 & 76.65\end{array}$

$\begin{array}{lllll}0 & 0 & 8 & 8 & 8\end{array}$

$\begin{array}{llllll}81.2 & 93.4 & 82.9 & 67.75 & 80.05 & 68.65\end{array}$

$\begin{array}{llllll}0.3874 & 0.3874 & 0.3874 & 0.3874 & 0.3874 & 0.3874\end{array}$

$\begin{array}{llllll}2.91 & 2 & 2 & 2 & 2 & 2\end{array}$

$\begin{array}{llllll}5.91 & 8.93 & 6.34 & 7.02 & 10.02 & 7.56\end{array}$

$0.026 \quad 0.024 \quad 0.025$

$84 \quad 99 \quad 86$

$5.710-8.422-6.110$ 


\begin{tabular}{|c|c|c|c|}
\hline $\mathrm{V}^{*}$, shear velocity, ft/s & 2.186 & 2.551 & 2.218 \\
\hline $\mathrm{V} * / \mathrm{w}$ & 1.093 & 1.276 & 1.109 \\
\hline $\begin{array}{l}\text { Bed transport coeff., k1, }(0.59 \text { if } \\
\text { k1 }\end{array}$ & $\begin{array}{l}\mathrm{V} * / \mathrm{w}<0.5 ; \\
0.64\end{array}$ & $\begin{array}{l}0.64 \text { if } \\
0.64\end{array}$ & $\begin{array}{l}5<\mathrm{V} * / \mathrm{w}<2 ; 0.69 \text { if } \mathrm{V} * / \mathrm{w}>2.0 \text { p. 33) } \\
0.64\end{array}$ \\
\hline $\mathrm{y}^{2}$, depth in contraction, ft & 6.63 & 7.14 & 7.15 \\
\hline ys, scour depth, ft (y2-y_bridge) & -0.39 & -2.87 & -0.41 \\
\hline
\end{tabular}

\begin{tabular}{|c|c|c|c|}
\hline \multicolumn{4}{|l|}{ ARMORING } \\
\hline D90 & 1.20444 & 1.20444 & 1.20444 \\
\hline D95 & 1.5382 & 1.5382 & 1.5382 \\
\hline Critical grain size,Dc, ft & 0.8264 & 0.2687 & 0.8649 \\
\hline Decimal-percent coarser than DC & 0.1819 & 0.6923 & 0.1698 \\
\hline depth to armoring, ft & 11.15 & 0.36 & 12.69 \\
\hline
\end{tabular}

Clear Water Contraction Scour in MAIN CHANNEL

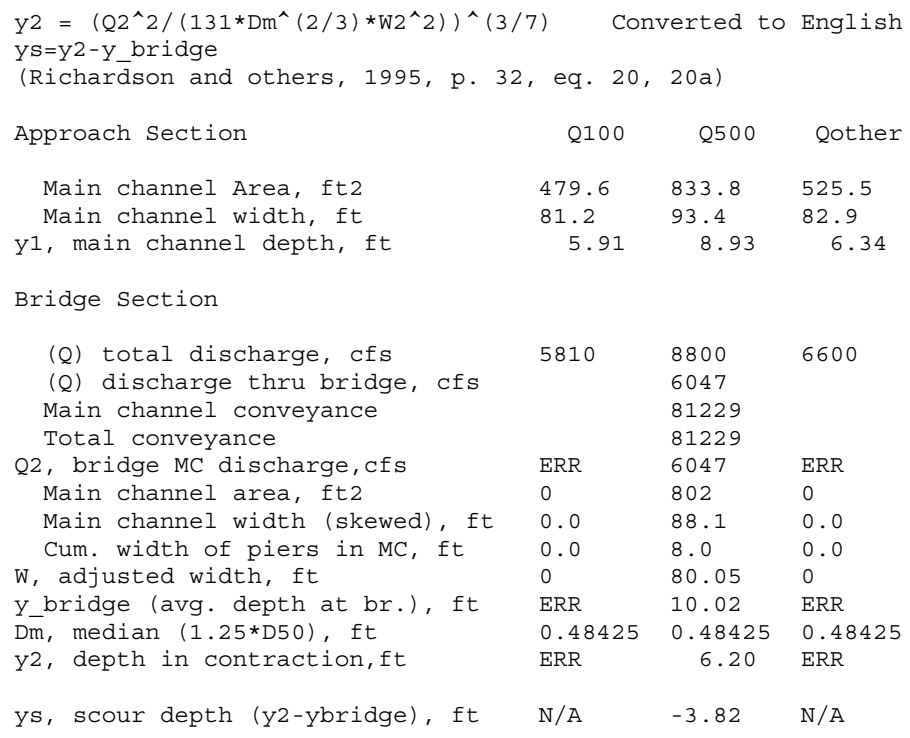

Pressure Flow Scour (contraction scour for orifice flow conditions)

$\mathrm{Hb}+\mathrm{Ys}=\mathrm{Cq} * \mathrm{qbr} / \mathrm{VC} \quad \mathrm{Cq}=1 / \mathrm{Cf} * \mathrm{CC} \quad \mathrm{Cf}=1.5 * \mathrm{Fr}^{\wedge} 0.43(<=1)$

Chang Equation CC=SQRT $[0.10(\mathrm{Hb} /(\mathrm{ya}-\mathrm{w})-0.56)]+0.79 \quad(<=1)$

(Richarson and others, 1995, p. 145-146)

$\begin{array}{llll} & Q 100 & Q 500 & \text { OtherQ } \\ \text { Q, total, cfs } & 0 & 8800 & 0\end{array}$

Q, thru bridge,

bridge, cfs

Total Conveyance, bridge

Main channel(MC) conveyance, bridge

$\begin{array}{llll}\text { Main channel (MC) conveyance, bridge } & 0 & 81229 & 0 \\ Q \text {, thru bridge MC, CfS } & \text { ERR } & 6047 & \text { ER }\end{array}$

10.98701 11. 77004 11. 11719

$\mathrm{Vc}$, critical velocity, m/s $\quad 3.3486763 .5873343 .388355$

Main channel width (skewed), ft $0 \quad 88.05 \quad 0$

Cum. width of piers in MC, ft 000

W, adjusted width, ft $\quad 0 \quad 80.05 \quad 0$

qbr, unit discharge, $\mathrm{ft}^{\wedge} 2 / \mathrm{s} \quad \mathrm{ERR} \quad 75.54029 \mathrm{ERR}$

qbr, unit discharge, $\mathrm{m}^{\wedge} 2 / \mathrm{s} \quad \mathrm{N} / \mathrm{A} \quad 7.017237 \mathrm{~N} / \mathrm{A}$

Area of full opening, $\mathrm{ft}^{\wedge} 2 \quad 001.8 \quad 0$

$\mathrm{Hb}$, depth of full opening, ft ERR $10.01624 \mathrm{ERR}$

$\mathrm{Hb}$, depth of full opening, $\mathrm{m} \quad \mathrm{N} / \mathrm{A} \quad 3.052801 \mathrm{~N} / \mathrm{A}$

Fr, Froude number, bridge MC $\quad 1 \quad 0.76 \quad 1$

Cf, Fr correction factor $(<=1.0) \quad 1.5 \quad 11.5$

ya, depth immediately upstream, ft $0 \begin{array}{lll}11.29 & 0 \\ 0 & 0 & 0\end{array}$

$\mathrm{CC}$, vert contrac correction $(<=1.0)$ ERR 0.970881 ERR

Ys, ft N/A $\quad-3.40573$ N/A

Abutment scour 


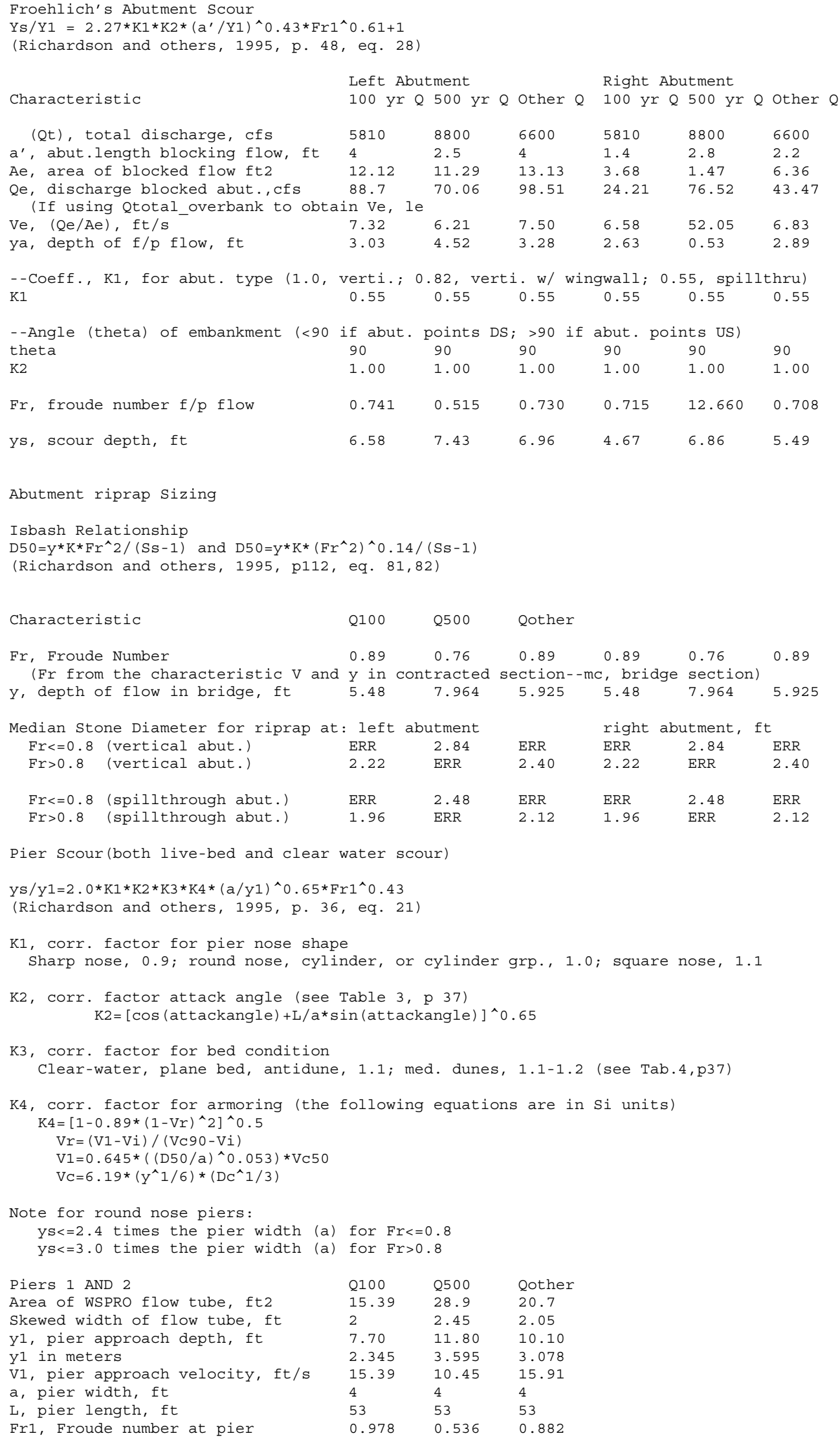

Pier Scour(both live-bed and clear water scour)

$\mathrm{Ys} / \mathrm{Y} 1=2.0 * \mathrm{~K} 1 * \mathrm{~K} 2 * \mathrm{~K} 3 * \mathrm{~K} 4 *(\mathrm{a} / \mathrm{Y} 1) \wedge 0.65 * \mathrm{Fr} 1 \wedge 0.43$

(Richardson and others, 1995, p. 36, eq. 21)

K1, corr. factor for pier nose shape

Sharp nose, 0.9; round nose, cylinder, or cylinder grp., 1.0; square nose, 1.1

K2, corr. factor attack angle (see Table 3, p 37) $\mathrm{K} 2=[\cos (\text { attackangle })+\mathrm{L} / \mathrm{a} * \sin (\text { attackangle })]^{\wedge} 0.65$

K3, corr. factor for bed condition

Clear-water, plane bed, antidune, 1.1; med. dunes, 1.1-1.2 (see Tab.4,p37)

K4, corr. factor for armoring (the following equations are in si units) $\mathrm{K} 4=\left[1-0.89 *(1-\mathrm{Vr})^{\wedge} 2\right]^{\wedge} 0.5$ $\mathrm{Vr}=(\mathrm{V} 1-\mathrm{Vi}) /(\mathrm{V} C 90-\mathrm{Vi})$

Note for round nose piers: ys $<=2.4$ times the pier width (a) for Fr<=0.8 ys $<=3.0$ times the pier width (a) for Fr>0.8

$\begin{array}{llll}\text { Piers 1 AND 2 } & \text { Q100 } & \text { Q500 } & \text { Qother } \\ \text { Area of WSPRO flow tube, ft2 } & 15.39 & 28.9 & 20.7 \\ \text { Skewed width of flow tube, ft } & 2 & 2.45 & 2.05 \\ \text { Y1, pier approach depth, ft } & 7.70 & 11.80 & 10.10 \\ \text { Y1 in meters } & 2.345 & 3.595 & 3.078 \\ \text { V1, pier approach velocity, ft/s } & 15.39 & 10.45 & 15.91 \\ \text { a, pier width, ft } & 4 & 4 & 4 \\ \text { L, pier length, ft } & 53 & 53 & 53 \\ \text { Fr1, Froude number at pier } & 0.978 & 0.536 & 0.882\end{array}$


Pier attack angle, degrees

K1, shape factor

$\mathrm{K} 2$, attack factor

K3, bed condition factor

D50, ft

$\mathrm{D} 50, \mathrm{~m}$

$\mathrm{D} 90, \mathrm{ft}$

D90, m

Vc50, critical velocity(D50), m/s

Vc90,critical velocity(D90), m/

$\mathrm{Vi}$, incipient velocity, $\mathrm{m} / \mathrm{s}$

Vr, velocity ratio

K4, armor factor

ys, scour depth (K4 applicable) ft

ys, scour depth (K4 not applied) ft

Piers 1 and 2

$\mathrm{K}$, pier shape coeff.

$\mathrm{V}$, char. aver. velocity, ft/s

D50, median stone diameter, ft

$\begin{array}{lll}0 & 0 & 0 \\ 1 & 1 & 1 \\ 1.00 & 1.00 & 1.00 \\ 1.1 & 1.1 & 1.1 \\ 0.3874 & 0.3874 & 0.3874 \\ 0.118074 & 0.118074 & 0.118074 \\ 1.20444 & 1.20444 & 1.20444 \\ 0.367095 & 0.367095 & 0.367095 \\ 3.500 & 3.759 & 3.662 \\ 5.109 & 5.486 & 5.345 \\ 1.995 & 2.142 & 2.087 \\ 0.866 & 0.312 & 0.848 \\ 0.99 & 0.76 & 0.99 \\ 10.87 & 7.48 & 11.41 \\ \text { ERR } & \text { ERR } & \text { ERR } \\ & & \end{array}$

Q100 Q500 Qother

$\begin{array}{lll}1.5 & 1.5 & 1.5\end{array}$

$\begin{array}{lll}12.21 & 7.54 & 12.71\end{array}$

$\begin{array}{lll}2.18 & 0.83 & 2.37\end{array}$ 